\title{
Possibilities of enhancing co-operation and co-ordination among MEAs in the biodiversity cluster
}

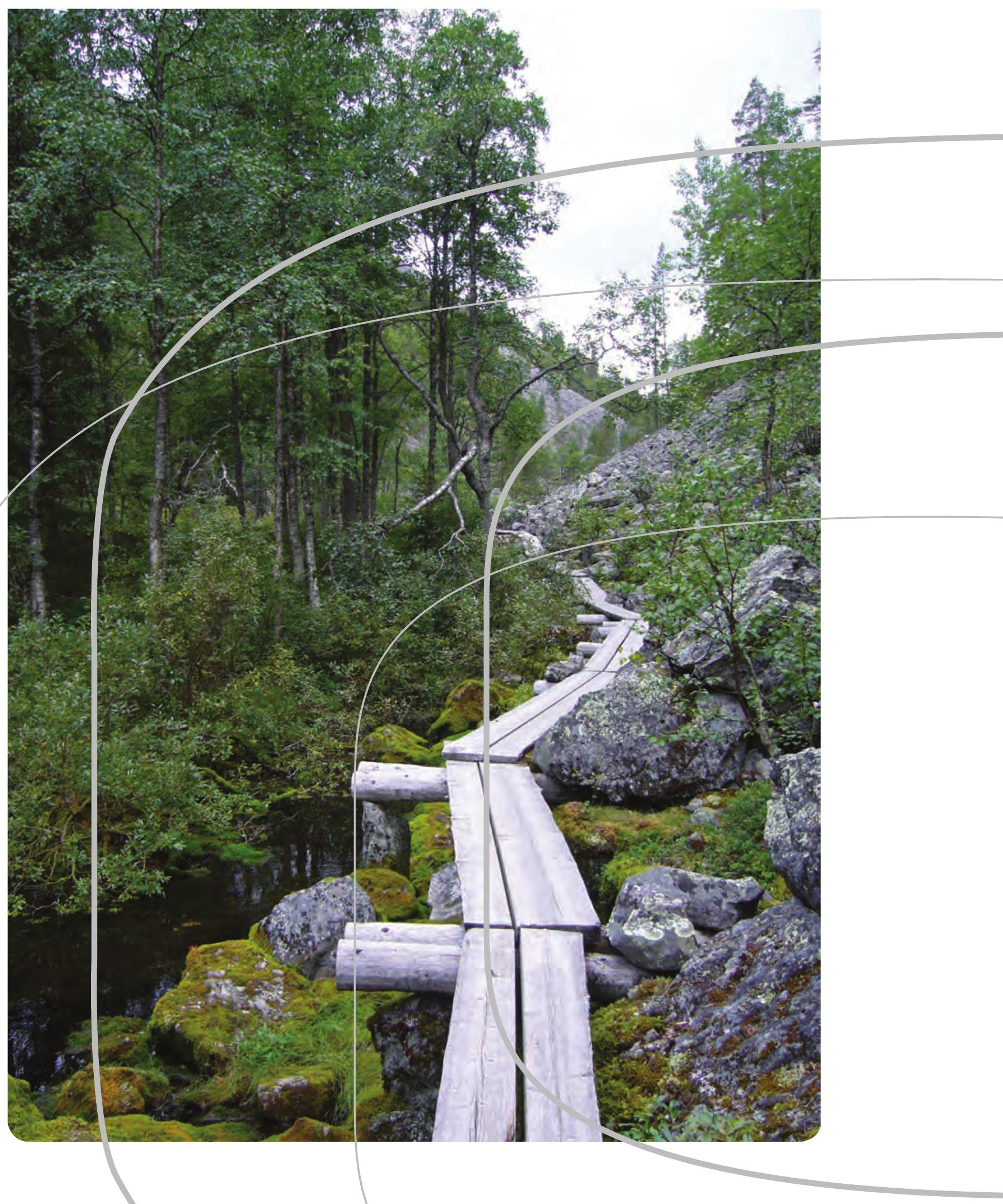



4 nordon 



\section{Possibilities of enhancing co- operation and co-ordination among MEAs in the bio- diversity cluster}

Niko Urho 
Possibilities of enhancing co-operation and co-ordination among MEAs in the biodiversity cluster

Environment/Biodiversity

TemaNord 2009:537

(C) Nordic Council of Ministers, Copenhagen 2009

ISBN 978-92-893-1873-0

Print: Kailow Express ApS

Cover:

Layout:

Cover photo:

Copies: 500

Printed on environmentally friendly paper

This publication can be ordered on www.norden.org/order. Other Nordic publications are available at www.norden.org/publications

Printed in Denmark

Nordic Council of Ministers

Store Strandstræde 18

DK-1255 Copenhagen K

Phone (+45) 33960200

Fax (+45) 33960202

www.norden.org

www.norden.org

\section{Nordic Council}

Store Strandstræde 18

DK-1255 Copenhagen K

Phone (+45) 33960400

Fax (+45) 33111870

\section{Nordic co-operation}

Nordic cooperation is one of the world's most extensive forms of regional collaboration, involving Denmark, Finland, Iceland, Norway, Sweden, and three autonomous areas: the Faroe Islands, Greenland, and Åland.

Nordic cooperation has firm traditions in politics, the economy, and culture. It plays an important rol in European and international collaboration, and aims at creating a strong Nordic community in a strong Europe.

Nordic cooperation seeks to safeguard Nordic and regional interests and principles in the global community. Common Nordic values help the region solidify its position as one of the world's most innovative and competitive. 


\section{Content}

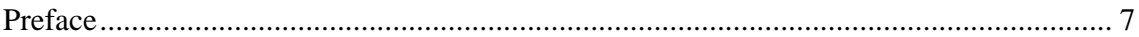

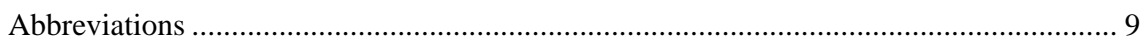

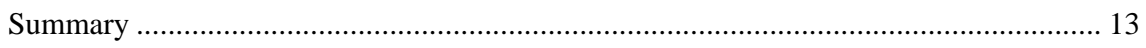

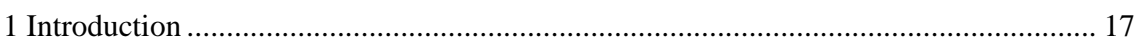

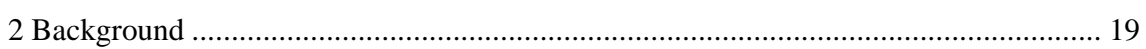

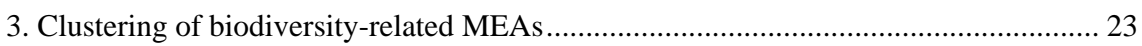

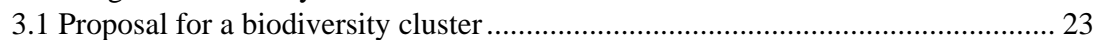

3.2 MEAs in the proposed biodiversity cluster...................................................... 28

3.3 Other MEAs and related processes that are linked to biodiversity ....................... 32

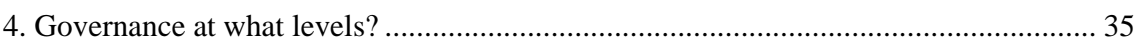

4.1 Country-driven processes .................................................................... 35

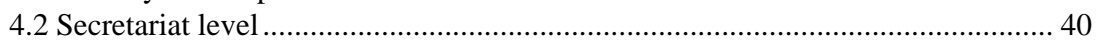

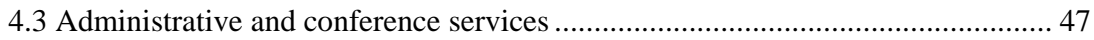

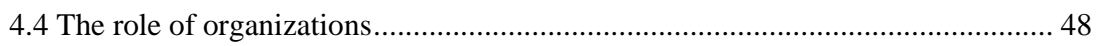

5. Areas for enhanced co-operation and co-ordination in the biodiversity cluster............ 53

5.1 Science policy interfaces on biodiversity ......................................................... 53

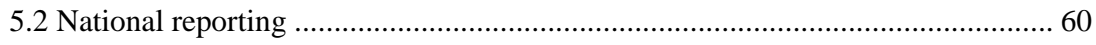

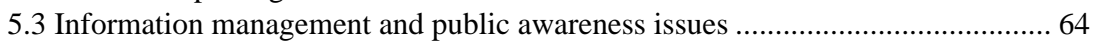

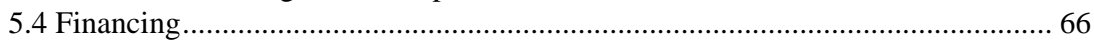

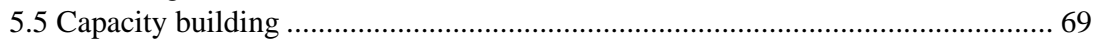

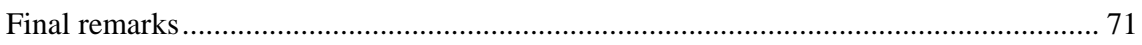

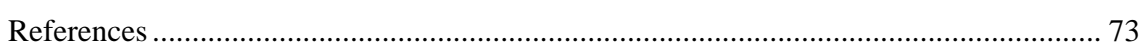

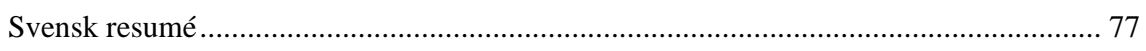

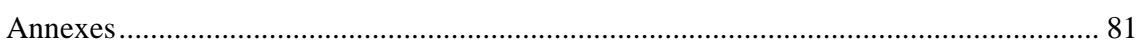





\section{Preface}

In August 2007 the Nordic Ministers of the Environment decided to initiate a pre-study to assess the possibilities of enhancing co-operation and co-ordination among multilateral environmental agreements (MEAs) in the biodiversity cluster. In May 2008 an independent environmental consultant was commissioned by the Nordic Council of Ministers to undertake the study. The study was carried out later during the same year and finalized in spring 2009. The Ministry of the Environment of Finland has been responsible for the overall co-ordination of the work.

The angle of analysis of the study is Nordic and the intention is to provide solutions from a Nordic viewpoint. Several information sources have been used, including literature studies as well as interviews with key persons. In September 2008 the preliminary results were presented and discussed at three expert meetings. Discussions were continued with several experts until the finalization of the report.

The author has benefited from valuable input and advice from a network of national and international experts. Counsellor Kerstin Stendahl from the Ministry of the Environment of Finland has provided significant input into the report, inter alia, by giving general guidance throughout the process, organizing expert meetings and providing in-depth information from many different aspects (e.g. the work done in the chemicals and waste cluster). The author also wishes to thank the following experts for their contributions to the work:

- Finland: Jussi Soramäki, Esko Jaakkola, Taina Veltheim, Marina von Weissenberg, Tita Korvenoja, Leena Karjalainen-Balk and Markku Aho

- Sweden: Lars Berg

- Norway: Tone Solhaug and Arlid Lindgaard

- Denmark: Christian Prip and Martin Schneekloth

In addition, the author would like to express his gratitude to the following persons who have contributed to the work: Robert Höft (CBD Secretariat), Sam Johnston (UNU), Peter Herkenrath (UNEP-WCMC) and Melissa Jaques (DEWHA). Last, but not least, the author wishes to thank the Nordic Council of Ministers, who financed and commissioned the study. 
The views expressed and conclusions drawn are the sole responsibility of the author, and should therefore be considered as a contribution to the knowledge-base enriching our discussions on means to create synergies among MEAs, thereby contributing to the strengthening of international environmental governance.

Helsinki, April 2009 


\section{Abbreviations}

AAPG

ABS

ACAP

ACCOBAMS

AHJWG

ASCOBANS

BLG

CBD

CEPA

CIFOR

CITES

CMS

COP

$\mathrm{CPF}$

CST

DEC

DELC

DEWA

DEWHA

ECOSOC

ELC

EMG

ENGO

EPBRS

EUROBATS

FAO

FRA

GBA

GBF

GC/GMEF

GEF

GEO

IAEA

ICCROM
Addis Ababa Principles and Guidelines

Access and Benefit Sharing

Agreement on the Conservation of Albatrosses and Petrels

Agreement on the Conservation of Cetaceans of the Black Sea and

Contiguous Atlantic Area

African-Eurasian Waterbird Agreement

Ad hoc joint working group on enhancing co-operation and co-ordination among the Basel, Rotterdam and Stockholm conventions Agreement on the Conservation of Small Cetaceans of the Baltic, North East Atlantic, Irish and North Seas

Biodiversity Liaison Group

Convention on Biological Diversity

Communication, education and public awareness

Centre for International Forestry Research

Convention on International Trade in Endangered Species

Convention on Migratory Species

Conference of Parties

Collaborative Partnership on Forests

Committee of Science and Technology (UNCCD)

Division for Environmental Conventions (UNEP)

Division for Environmental Law and Conventions (UNEP)

Division of Early Warning and Assessment (UNEP)

Australian Government's Department of the Environment, Water,

Heritage and the Arts

UN Economic and Social Committee

Environmental Law Centre (IUCN)

Environmental Management Group

Environmental non-governmental organization

European Platform for Biodiversity Research Strategy

Agreement on the Conservation of Populations of European Bats

Food and Agriculture Organization of the United Nations

Forest Resources Assessment

Global Biodiversity Assessment

Global Biodiversity Forum

Governing Council/Global Ministerial Environment Forum (UNEP)

Global Environment Facility

Global Environment Outlook

International Atomic Energy Agency

International Centre for the Study of the Preservation and Restoration

of Cultural Property 


\begin{tabular}{|c|c|}
\hline ICOMOS & International Council of Monuments and Sites \\
\hline ICRAF & World Agroforestry Centre \\
\hline ICRW & International Convention on the Regulation of Whaling \\
\hline IEG & International environmental governance \\
\hline IFPGRFA & International Treaty on Plant Genetic Resources for Food and Agriculture \\
\hline IGO & Intergovernmental organization \\
\hline ILO & International Labour Organization \\
\hline IMO & International Maritime Organization \\
\hline IMoSEB & International Mechanism on Scientific Expertise on Biodiversity \\
\hline IOP & International Organization Partners of the Convention (Ramsar) \\
\hline IOSEA & Indian Ocean and South-East Asia \\
\hline IPBES & $\begin{array}{l}\text { Intergovernmental Science-Policy Platform on Biodiversity and } \\
\text { Ecosystem Services }\end{array}$ \\
\hline IPCC & Intergovernmental Panel on Climate Change \\
\hline ISC & International Steering Committee \\
\hline ITTO & International Tropical Timber Organization \\
\hline IUCN & International Union for Conservation of Nature \\
\hline IUFRO & International Union of Forestry Research Organizations \\
\hline IWC & International Whaling Commission \\
\hline IWMI & International Water Management Institute \\
\hline JIU & Joint Inspection Unit \\
\hline JLG & Joint Liaison Group \\
\hline JWP & Joint Work Plan \\
\hline MA & Millennium Ecosystem Assessment \\
\hline MEA & Multilateral Environmental Agreement \\
\hline MLS & Multilateral System of Access and Benefit-sharing (ITPGRFA) \\
\hline MOP & Meeting of Parties \\
\hline $\mathrm{MoU}$ & Memorandum of Understanding \\
\hline NAP & National Action Programme (UNCCD) \\
\hline NBSAP & National Biodiversity Strategies and Actions Plans \\
\hline NLBI & Non-Legally Binding Instrument on All Types of Forests \\
\hline PGRFA & Plant genetic resources for food and agriculture \\
\hline PIC & Convention on the Prior Informed Consent Procedure for Certain \\
\hline & Hazardous Chemicals and Pesticides in International Trade \\
\hline POPs & Convention on Persistent Organic Pollutants \\
\hline RAP & Regional Action Programme \\
\hline SBSTA & Subsidiary Body for Scientific and Technological Advice (UNFCCC) \\
\hline SBSTTA & Subsidiary Body on Scientific, Technical and Technological Advice (CBD) \\
\hline SC & Scientific Council (CMS) \\
\hline SCBD & Secretariat of the Convention on Biological Diversity \\
\hline SRAP & Sub-Regional Action Programme (UNCCD) \\
\hline STRP & Scientific and Technical Review Panel (Ramsar) \\
\hline UNCCD & United Nations Convention to Combat Desertification \\
\hline UNDP & United Nations Development Program \\
\hline UNEO & United Nations Environment Organization \\
\hline
\end{tabular}




$\begin{array}{ll}\text { UNEP } & \text { United Nations Environment Programme } \\ \text { UNESCO } & \text { United Nations Scientific and Cultural Organization } \\ \text { UNFCCC } & \text { United Nations Framework Convention on Climate Change } \\ \text { UNFF } & \text { United Nations Forum on Forests } \\ \text { UNOG } & \text { United Nations Office in Geneva } \\ \text { UNON } & \text { United Nations Office in Nairobi } \\ \text { UNU } & \text { United Nations University } \\ \text { WCMC } & \text { World Conservation Monitoring Centre } \\ \text { WHC } & \text { World Heritage Convention } \\ \text { WTO } & \text { World Trade Organization } \\ \text { WWF } & \text { World Wide Fund for Nature }\end{array}$





\section{Summary}

Discussions on improving the international environmental governance (IEG) have been going on for over a decade. Currently, it seems unlikely that a dramatic restructuring of the IEG will take place in the near future. This is why a step-by-step approach of clustering is being introduced as one way of enhancing the IEG process. By adopting a "bottom-up" approach and examining the MEAs in thematic clusters, it is possible to find solutions for enhancing co-operation and co-ordination among the MEAs on a smaller scale. This will enable the building up of a more coherent IEG where national needs are addressed and where form follows function.

There are currently 155 conventions that deal with biodiversity at some level. Four selection criteria have been used to identify the MEAs that would constitute a coherent and well-designed biodiversity cluster:

1. The MEA concerns primarily the conservation and/or sustainable use of biodiversity.

2. The MEA is actively engaged in co-operation with other MEAs that concern biodiversity.

3. The MEA cannot be placed in some other cluster.

4. The MEA is global in nature and the number of Contracting Parties exceeds 90 .

Based on these criteria, the initial biodiversity cluster could include the following six MEAs:

- Convention on Biological Diversity (CBD)

- Convention on International Trade in Endangered Species (CITES)

- Convention on Migratory Species (CMS)

- Ramsar Convention on Wetlands

- World Heritage Convention (WHC)

- International Treaty on Plant Genetic Resources for Food and Agriculture (ITPGRFA)

Current activities for enhancing synergies among biodiversity-related MEAs have been undertaken in a fairly ad hoc fashion and with no particular coordinated approach in mind. This has resulted in the duplication of work, on the one hand, and unexplored areas for enhancing synergies, on the other. It can also be argued that to date few - if any - truly synergistic solutions have been introduced to the biodiversity-related MEAs. 
This report contains 12 recommendations for enhancing co-operation and co-ordination among the MEAs in the initial biodiversity cluster. The recommendations are preliminary and do not represent a comprehensive analysis. The main findings and recommendations are summarized below.

The numbers of weeks spent on meetings of the supreme decisionmaking bodies of the six MEAs in the biodiversity cluster have grown rapidly since the Stockholm Conference in 1972. Arranging simultaneous or back-to-back meetings of the supreme decision-making bodies could bring benefits (e.g. reduced overall costs and reduced inconsistencies in decision-making); but, at the same time, it will bring various practical disadvantages (e.g. too-long, crowded and/or costly meetings) that make this an unfeasible option. In contrast, the practice of arranging back-toback meetings of the different bodies within the MEAs should be further encouraged when this would bring benefits (Recommendation 1). In addition, the overgrown agendas of the meetings of the supreme decision-making bodies should be reduced by focusing more clearly on the most relevant issues. This could enable a gradual shortening of the duration of the meetings and also help in setting priorities for implementation (Recommendation 2).

The secretariats of the MEAs in the biodiversity cluster are located around the world and they are administered by different intergovernmental organizations (IGOs). There have been discussions on the feasibility of co-locating MEA secretariats, but the prospects for dramatic reorganization of the secretariats in the biodiversity cluster appears remote. The only experience from merging secretariats comes from the formerly independent Secretariat of the Agreement on the Conservation of Small Cetaceans of the Baltic, North East Atlantic, Irish and North Seas (ASCOBANS) that was merged into its mother convention (CMS) in 2006. Although the final result of this co-location is still unclear, the colocation of smaller secretariats appears practicable and should be further encouraged. When deciding to establish secretariats for new MEAs that concern the conservation and/or sustainable use of the different components of biodiversity, co-location with existing secretariats in the biodiversity cluster should be pursued. In order to further enhance cooperation between MEA secretariats and increase coherence in the biodiversity cluster UNEP-administration of the Ramsar Secretariat should be considered (Recommendation 3).

Co-operation at the level of the secretariats of the MEAs in the biodiversity cluster is already well developed. The six MEAs in the biodiversity cluster cooperate at the secretariat level through the biodiversity liaison group (BLG) and through bilateral arrangements (MoUs and joint work programmes). The estblishment of the BLG in 2004 should be considered a significant step forward towards the clustering of the MEAs. However, the secretariats lack legal authority to organize genuine cooperation and co-ordination between the MEAs, therefore, the practical 
outcomes of the BLG have remained limited. In summary, by limiting cooperation to the secretariat level the conventions have not been able to effectively enhance synergies between the MEAs or even properly coordinate existing initaitives.

The report highlights that the Contracting Parties should assume a greater role in creating synergies between the MEAs. The work of the Ad Hoc Joint Working Group on enhancing co-operation and co-ordination between the Basel, Rotterdam and Stockholm conventions (AHJWG) has shown the benefits of a country-driven process, whereby, structures and organizations are created based on national needs. The model cannot, however, be directly applied to the biodiversity cluster, since in regard to scope and number of MEAs, it is much larger. Nevertheless, the BLG could be transformed into a forum that would also include the Contracting Parties. It is important to assess what this would mean in practical terms, inter alia, the number of parties per convention and region that would take part in its work (Recommendation 4).

UNEP plays a key role in the biodiversity cluster, since it administers three MEAs (CBD, CMS and CITES) and the seven regional agreements of the CMS. The European Union has made a proposal to upgrade UNEP to a United Nations Environment Organization (UNEO). However, in order to be able to discuss the creation of a UN specialized agency it is essential to first clarify the composition of the different clusters and then work step by step to enhance synergies between the MEAs in the clusters and to gradually increase the confidence of the Contracting Parties (Recommendation 5).

The MEAs in the biodiversity cluster rely on a variety of sciencepolicy interfaces. However, the current fragmented landscape of sciencepolicy interfaces is unable to provide the required policy support for coherent and effective decision-making. The scientific and technical bodies of the MEAs are increasingly being politicised and they lack adequate financial and human resources. In addition, there is no fully developed science-assessment mechanism for biodiversity at the international level. There is a need for an independent panel or platform that would provide different clients and knowledge users, in particular the scientific bodies of the MEAs in the biodiversity cluster, with timely, credible and legitimate advice. UNEP's initiative to establish an intergovernmental science-policy platform on biodiversity and ecosystem services (IPBES) should be supported (Recommendation 6).

Harmonization of national reporting is widely mentioned as one of the most important areas for reducing administrative burden and, hence, facilitating national implementation. Numerous harmonization processes have been conducted and many are under way; however, they have all been fairly uncoordinated and have resulted in the duplication of work and different approaches to harmonization. If progress is to be made with the harmonization of reporting, then governments need to be involved. A 
strengthened BLG, consisting of government representatives, should look at harmonization of reporting by building on existing initiatives (Recommendation 7). In addition, a strengthened BLG could participate, inter alia, in the further development of information management tools and a joint website (Recommendation 8), and in the development of a common approach to awareness and outreach activities among the MEAs in the biodiversity cluster (Recommendation 9).

Apart from the CBD, the MEAs in the biodiversity cluster do not have a financial mechanism. The financial potential of the other MEAs, in comparison with the funds allocated by the Global Environment Facility (GEF) for the CBD, indicates that they have no chance of becoming really effective as long as the present situation continues. The GEF should be developed and strengthened by including more focal areas and more treaty-specific services for the MEAs in the biodiversity cluster (Recommendation 10). The development of a funding mechanism similar to the multilateral fund for the implementation of the Montreal Protocol would also allow more funding for the MEAs in the biodiversity cluster. In order to increase the overall funding for biodiversity, the engagement of the business community should be encouraged through the adoption of national and regional Business and Biodiversity initiatives (Recommendation 11).

Capacity-building activities often lack coherence. In bilateral development co-operation, a common approach to the implementation of biodiversity-related MEAs should be developed. For example, the objectives of the MEAs in the biodiversity cluster should be integrated into the National Biodiversity Strategies and Actions Plans (NBSAP) implemented under the CBD. In addition, enhancing co-operation between the different Focal Points of the MEAs in the biodiversity cluster would facilitate the exchange of information and enable the creation of networks that would greatly enhance the implementation of the MEAs (Recommendation 12). 


\section{Introduction}

This report provides an analysis of possibilities for enhancing cooperation and co-ordination among multilateral environmental agreements (MEAs) in the biodiversity cluster. It explores solutions for reducing administrative burden and for maximizing the efficient use of resources, while respecting the legal autonomy of the MEAs, with the aim of strengthening the implementation of MEAs at the national, regional and global levels. The report contributes to the discussions on enhancing international environmental governance (IEG).

The Millennium Ecosystem Assessment (MA 2005a) revealed that humans have caused the species extinction rate to increase by 1000 times compared to historical background rates and emphasized that the rate of biodiversity loss is further accelerating. The Assessment also showed that 60 per cent of all ecosystem services are being degraded or used unsustainably, which is seriously impairing human well-being. Historically, the decrease of biological diversity has occurred mostly in developed countries. However, during the past decades the problem of biodiversity loss has shifted more profoundly to developing countries that are now witnessing a mass extinction of species. The accelerating rate of biodiversity loss and ecosystem degradation shows that the threat of losing the diversity of earth's living resources that we depend on is severe and needs increased attention.

The problem is not the inability of policy-makers to negotiate effective institutions. Indeed, the international community has actively tried to find solutions for dealing with global environmental problems and, in fact, our efficiency has resulted in quite a number of institutions to address the problems. However, the institutions entrusted to manage the environment have not been created systematically, but rather have developed organically as environmental problems appeared on the political agendas (Chambers 2008). As an arguably cruel twist of fate, this ad hoc development has led to fragmentation and a lack of co-ordination which has reduced institutional performance to deal with environmental problems (Chambers 2008).

Now that the global environmental architecture is more mature and we can more clearly see the whole picture we need to build synergies among the various institutions. The institutional landscape is too complex to be addressed through a singular approach, such as creating a United Nations Environment Organization (UNEO). Rather, the first step could be to place MEAs into thematic clusters and tailor synergistic solutions to the specific institutional structures and arrangements. This report will concentrate only on a small fraction of the IEG - the biodiversity cluster - 
that is to say, global MEAs that primarily concern the different components of biodiversity.

The second section will provide background information about the IEG process and introduce the concept of clustering. Section 3 will first identify the MEAs that constitute a coherent and functional biodiversity cluster and then introduce the MEAs. The governance of the biodiversity cluster is discussed in Section 4. In Section 5 different areas for enhanced co-operation are discussed, including science-policy interfaces for biodiversity, national reporting, information management and public awareness issues, financing and capacity building. The report provides twelve recommendations that are embedded in the text. 


\section{Background}

Since the Stockholm Conference in $1972^{1}$, the international community has actively tried to negotiate effective solutions for dealing with global environmental threats. As no one could have predicted the magnitude of environmental problems that would arise before the 21st century, global environmental solutions have been considered in isolation (Kanie 2007; Chambers 2008). This has resulted in highly fragmented international environmental governance (IEG), which is especially obvious in the case of MEAs. Today, more than 500 MEAs are registered with the United Nations (Knigge et al. 2005; Najam et al. 2006).

Over the last decade the need for enhancing international environmental governance has repeatedly come up in academic and policy discussions. In 2002, the UNEP Governing Council/Global Ministerial Environment Forum (GC/GMEF) adopted the "Cartagena Package on International Environmental Governance” that recommends, inter alia, improving coordination and coherence between MEAs with comparable areas of focus ${ }^{2}$. The process on international environmental governance was highlighted at the 2005 World Summit, where Heads of State adopted the World Summit Outcome Document, in which they agree to explore the possibility of creating a more coherent institutional framework, including a more integrated structure, for environmental activities in the United Nations system ${ }^{3}$.

For the follow-up to the resolution, the UN Secretariat initiated "the Informal Consultative Process on the Institutional Framework for the United Nations' Environmental Activities", co-chaired by Mexico and Switzerland. In 2007, the co-chairs presented an "Options Paper" that includes seven Building Blocks for strengthening the IEG ${ }^{4}$. The Building Blocks are intended to provide a flexible framework for further development. MEAs are discussed in Building Block 3 of the Options Paper that presents an option for the clustering of MEAs. Clustering is

"grouping a number of international environmental regimes together so as to make them more efficient and effective” (von Moltke 2005).

Clustering provides opportunities for synergies, particularly within each cluster, where agreements have much in common in terms of issues to be addressed.

\footnotetext{
${ }^{1}$ United Nations Conference on the Human Environment.

${ }^{2}$ Doc. UNEP/GC/7/1, 13-15 February 2002, annex, para. 27.

${ }^{3} \mathrm{~A} / \mathrm{RES} / 60 / 1$ (para. 169).

${ }^{4}$ International Consultative Process on the Institutional Framework for the United Nations' Environmental Activities, Co-Chairs' Options Paper, New York, 14 June 2007.
} 
The issue of synergies has also been addressed within the conventions themselves. Many voluntary mechanisms now act as bridges between secretariats of the conventions. Several bilateral memoranda of understanding (MoU) and joint work plans (JWP) have been created between biodiversity-related conventions. In addition, two liaison groups have been established: the biodiversity liaison group (BLG) that involves six biodiversity-related conventions and the joint liaison group (JLG) that involves the conventions on climate, biodiversity and desertification. These will be discussed in more detail below.

To date, there exists no common understanding for a biodiversity cluster. If one looks at biodiversity in the widest perspective, 155 conventions deal with biodiversity at some level (Knigge et al. 2005; Najam et al. 2006). However, most of the conventions are regional agreements and have only a limited amount of parties. The following list covers the most significant global MEAs and related processes concerning biodiversity:

$\begin{array}{ll}\text { CBD } & \text { Convention on Biological Diversity } \\ \text { CITES } & \text { Convention on International Trade in Endangered Species } \\ \text { CMS } & \text { Convention on Migratory Species } \\ \text { Ramsar } & \text { Ramsar Convention on Wetlands } \\ \text { WHC } & \text { World Heritage Convention } \\ \text { ITPGRFA } & \begin{array}{l}\text { International Treaty on Plant Genetic Resources for Food } \\ \text { and Agriculture }\end{array} \\ \text { UNCCD } & \begin{array}{l}\text { Convention to Combat Desertification } \\ \text { ICRW }\end{array} \\ \text { International Convention for the Regulation of Whaling } \\ \text { UNFF } & \text { United Nations Forum on Forests }\end{array}$

Different views for a biodiversity cluster stem from separate discussions in different political fora. Most importantly, divergent views have arisen from an 'internal" split between Member States of the General Assembly (GA), on the one side, and Parties to the MEAs, on the other. The cochairs of the New York-based "Informal Consultative Process..." presented in the Options Paper (July 2007) a suggestion for a "conservation cluster" that differs from the group of MEAs that already co-operate through the biodiversity liaison group established in 2004 by the CBD (Figure 1) (UN 2007). If assessed on the basis of activities at the secretariat level the BLG can be perceived as a biodiversity cluster. 


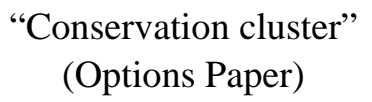

"Biodiversity-related conventions" (Biodiversity liaison group)

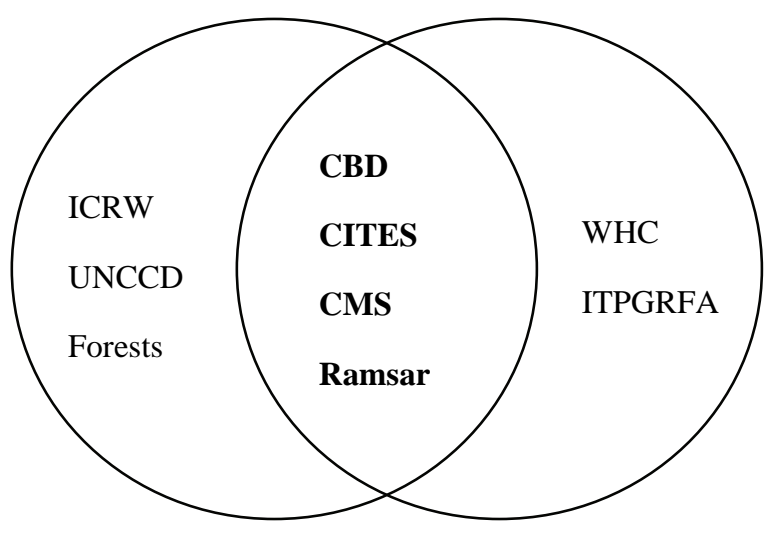

Figure 1. The "conservation cluster" presented in the Options Paper differs from the group of MEAs that are part of the biodiversity liaison group. While both include six MEAs only four (CBD, CITES, CMS and Ramsar) are the same. The Options Paper suggests including also the ICRW, UNCCD and forests in the "conservation cluster". Although, the WHC and ITPGRFA are also part of the biodiversity liaison group, these were not brought up in the Options Paper. The conventions in the biodiversity liaison group are often referred to as the biodiversity-related conventions.

To date, the most striking example of increasing synergies between MEAs comes from the conventions in the chemicals and waste cluster (Basel, Rotterdam and Stockholm Conventions) ${ }^{5}$. The work started in 2006, when the Conferences of Parties (COPs), each by their own decisions, agreed to establish an ad hoc joint working group on enhancing co-operation and coordination between the Basel, Rotterdam and Stockholm Conventions (AHJWG). The group consisted of 45 members; 15 signatories from each of the three conventions. The AHJWG convened three times and agreed on a recommendation that includes concrete proposals for joint programmatic and administrative activities. These include, inter alia, harmonization of national reporting, developing joint capacity building activities, joint outreach and public awareness activities, establishing joint services and functions, and even organizing a one-off simultaneous extraordinary meeting of the COPs to the three conventions.

The recommendation of the AHJWG is being hailed as a breakthrough and a success, because it is the first process to make real progress within the IEG discussions. The process is perceived as an innovative "bottomup" approach in that it is country-driven and engages the parties to the conventions in the design of and follow-up to synergistic efforts. The recommendation of the AHJWG has already been adopted by the Basel

\footnotetext{
${ }^{5}$ The Convention on the Control of Transboundary Movements of Hazardous Wastes and their Disposal (1989); the Convention on the Prior Informed Consent Procedure for Certain Hazardous Chemicals and Pesticides in International Trade (1999); the Convention on Persistent Organic Pollutants (2001).
} 
COP 9 as well as the PIC COP4. For the recommendation to come fully into effect it still needs to be adopted by the POPs COP4 to be held in Geneva from 4 to 8 May 2009.

The MEAs in the chemicals and waste cluster provide a good starting point for working in clusters to increase coherence of the IEG system, as the cluster forms a relatively small and uniform group of MEAs. In addition, the Basel, PIC and POPs Secretariats are co-located in Geneva. However, these are only first steps and much more significant work remains to be done. Working step by step and slowly building the confidence and trust of the Parties is imperative, thus no significant change can be expected in one night.

Based on these positive experiences, a process of enhancing cooperation and co-ordination among the MEAs in the biodiversity cluster could be considered (see Recommendation 4). Opportunities for enhanced co-ordination in the biodiversity cluster have received particular attention and exhibit promise. 


\section{Clustering of biodiversity- related MEAs}

This section will first outline a proposal for a biodiversity cluster and then introduce the conventions. The biodiversity cluster represents a possible model and should be subject to further discussion. The conventions are described by presenting briefly the main purpose of the MEAs, as well as the main instruments for achieving the goals.

\subsection{Proposal for a biodiversity cluster}

The formation of clusters is a matter of broad discussion and careful consideration. Ultimately, the decision for forming a cluster is under the authority of the governing bodies of the MEAs. Based on the results of expert interviews and workshops, the following selection criteria have been used to identify the MEAs that constitute a coherent and well-designed biodiversity cluster:

1. The MEA concerns primarily the conservation and/or sustainable use of different components of biodiversity (ecosystems, species and/or genetic resources).

2. The MEA is seeking to cooperate with other MEAs that concern biodiversity and is perceived by other MEAs as a favourable cooperation partner.

3. There are no strong arguments in favour of placing the MEA in some other cluster.

4. The MEA is global in nature and the number of Parties exceeds 90.

In addition, in order to create a coherent cluster that is manageable in practical terms it has been seen as necessary to limit the size of the initial biodiversity cluster to four to six MEAs. These criteria will enable an initial biodiversity cluster to be outlined, as well as another group of MEAs that are linked to biodiversity:

\section{The biodiversity cluster}

The biodiversity cluster should consist of six MEAs - CBD, CITES, CMS, Ramsar, WHC and ITPGRFA - that profoundly concern the conservation and sustainable use of biodiversity and that are already cooperating at the secretariat level through the biodiversity liaison group. 


\section{Other MEAs and related processes that are linked to biodiversity}

The UNCCD, ICRW and UNFF are linked to biodiversity, but should not be placed in the initial biodiversity cluster since they either have strong arguments in favour of also being placed in some other cluster or past experiences have shown that co-operation is not easily achieved.

The MEAs in the proposed biodiversity cluster have developed three clearly distinct approaches that focus on different components of biodiversity: 1) ecosystems, 2) species, and/or 3) genetic resources. The CBD has the widest scope and covers all ecosystems, species and genetic resources. The CMS, CITES, Ramsar, WHC and ITPGRFA restrict their regimes to address specific components of biodiversity (Figure 2). It is important to note that the different approaches developed under each convention came about to meet distinct needs, and that their particular value must be maintained while seeking to increase synergies among the MEAs (SCBD 2006a).

\begin{tabular}{cccccc} 
Ramsar & WHC & CITES & CMS & CBD & Cartagena \\
1971 & 1972 & 1975 & 1983 & $19 \overline{9} \overline{3}$ & ITPGRFA \\
Protocol & 2004 \\
Ecosystems & Species & & General & Genetic resources \\
\hline
\end{tabular}

Figure 2. The MEAs in the biodiversity cluster address different components of biodiversity.

The UNCCD does not primarily address biodiversity, rather it concerns primarily sustainable land use and can be characterized as a land convention (Knigge et al. 2006). However, it is important to understand that dry and sub-humid lands include many environments that are threatened by the loss of biodiversity. The programme of work on dry and subhumid lands, adopted by the CBD in 2000, is of particular relevance for the conservation of biodiversity in dry areas and sub-humid areas.

The issue of UNFF is complex - there are equal grounds to place UNFF in the climate cluster as in the biodiversity cluster. It is obvious that forests hold a position under the Kyoto Protocol, which is likely to strengthen in post-Kyoto schemes; therefore, the role of forests is attracting increasing attention in the climate negotiations. Likewise, the inclusion of forests in the biodiversity cluster is well-founded, since a great amount of biodiversity can be found in tropical forests. Many biodiversity-related MEAs address forest issues; the expanded programme of work on forest biodiversity, adopted by CBD in 2002, is of particular relevance for the conservation of biodiversity in forests.

Even though the ICRW has an important role in safeguarding the diversity of whale species, in the initial stage it might be appropriate not to include the convention in the biodiversity cluster. There has been concern that the conflict between those who seek commercial utilization of whales and those 
who seek protection for all whales has jeopardized the future role of the ICRW (Calestous 2008). In this context, it is important to emphasize that the International Whaling Commission (IWC) is actively trying to resolve the issues that have polarized a number of the debates within the convention. When the issues are resolved and the future role of the IWC is ensured, the inclusion of the ICRW in the biodiversity cluster should be considered.

Characteristics of MEAs in the biodiversity cluster and other MEAs and processes that have clear links to biodiversity are presented in Table 1. CMS is the only MEA that operates like an umbrella convention, under which seven independent regional agreements have been adopted, as outlined in Table 2.

Table 1. Characteristics of MEAs in the biodiversity cluster and other MEAs and related processes that are linked to biodiversity.

\begin{tabular}{|c|c|c|c|c|}
\hline MEA & Objective & Scope & $\begin{array}{l}\text { No. of } \\
\text { partiesl } \\
\text { members }\end{array}$ & $\begin{array}{l}\text { Year of } \\
\text { entry into } \\
\text { force }\end{array}$ \\
\hline CBD & $\begin{array}{l}\text { The conservation of biological diversity, the } \\
\text { sustainable use of its components, and the } \\
\text { fair and equitable sharing of the benefits } \\
\text { arising from commercial and other utilization } \\
\text { of genetic resources. }\end{array}$ & $\begin{array}{l}\text { All ecosystems, species, and } \\
\text { genetic resources. }\end{array}$ & 191 & 1993 \\
\hline Cartagena & $\begin{array}{l}\text { To ensure an adequate level of protection in } \\
\text { the field of the safe transfer, handling and use }\end{array}$ & $\begin{array}{l}\text { Applies to the transboundary } \\
\text { movement, transit, handling and }\end{array}$ & 147 & 2003 \\
\hline Protocol & $\begin{array}{l}\text { of living modified organisms resulting from } \\
\text { modern biotechnology that may have adverse } \\
\text { effects on the conservation and sustainable } \\
\text { use of biological diversity, taking also into } \\
\text { account risks to human health, and specifi- } \\
\text { cally focusing on transboundary movements. }\end{array}$ & $\begin{array}{l}\text { use of all living modified organ- } \\
\text { isms that may have adverse } \\
\text { effects on the conservation and } \\
\text { sustainable use of biological } \\
\text { diversity, taking also into account } \\
\text { risks to human health. }\end{array}$ & & \\
\hline CITES & $\begin{array}{l}\text { Ensure that international trade in specimens } \\
\text { of wild animals and plants does not threaten } \\
\text { their survival. }\end{array}$ & $\begin{array}{l}\text { More than } 30,000 \text { plant and } \\
\text { animal species }\end{array}$ & 173 & 1975 \\
\hline CMS & $\begin{array}{l}\text { To conserve terrestrial, marine and avian } \\
\text { migratory species throughout their range. }\end{array}$ & Migratory species & 109 & 1983 \\
\hline Ramsar & $\begin{array}{l}\text { The conservation and wise use of all wetlands } \\
\text { through local, regional and national actions } \\
\text { and international co-operation, as a contribu- } \\
\text { tion towards achieving sustainable develop- } \\
\text { ment throughout the world. }\end{array}$ & $\begin{array}{l}\text { Wetland ecosystems. The Ramsar } \\
\text { list has currently } 1833 \text { sites. }\end{array}$ & 159 & 1971 \\
\hline WHC & $\begin{array}{l}\text { The primary mission of the WHC is to identify } \\
\text { and conserve the world's cultural and natural } \\
\text { heritage, by drawing up a list of sites whose } \\
\text { outstanding values should be preserved for all } \\
\text { humanity and to ensure their protection } \\
\text { through a closer co-operation among nations. }\end{array}$ & $\begin{array}{l}166 \text { natural, } 660 \text { cultural and } 25 \\
\text { mixed properties, in } 141 \text { States } \\
\text { Parties }\end{array}$ & 182 & 1972 \\
\hline ITPGRFA & $\begin{array}{l}\text { The conservation and sustainable use of plant } \\
\text { genetic resources for food and agriculture and } \\
\text { the fair and equitable sharing of the benefits } \\
\text { arising out of their use, in harmony with the } \\
\text { Convention on Biological Diversity, for sus- } \\
\text { tainable agriculture and food security. }\end{array}$ & $\begin{array}{l}\text { All plant genetic resources for } \\
\text { food and agriculture, while its } \\
\text { Multilateral System of Access and } \\
\text { Benefit-sharing covers a specific } \\
\text { list of } 64 \text { crops and forages. }\end{array}$ & 120 & 2004 \\
\hline UNCCD & $\begin{array}{l}\text { To combat desertification and mitigate the } \\
\text { effects of drought in countries experiencing } \\
\text { serious drought and/or desertification, particu- } \\
\text { larly in Africa. }\end{array}$ & $\begin{array}{l}\text { Arid, semi-arid and/or dry sub- } \\
\text { humid areas affected or threat- } \\
\text { ened by desertification }\end{array}$ & 193 & 1996 \\
\hline ICRW & $\begin{array}{l}\text { Provide for the proper conservation of whale } \\
\text { stocks and thus make possible the orderly } \\
\text { development of the whaling industry. }\end{array}$ & $\begin{array}{l}\text { All species of large whale, compe- } \\
\text { tence over small whales disputed }\end{array}$ & 91 & 1948 \\
\hline UNFF & $\begin{array}{l}\text { Promote management, conservation and } \\
\text { sustainable development of all types of } \\
\text { forests and to strengthen long-term political } \\
\text { commitment to this end. }\end{array}$ & All types of forests & - & - \\
\hline
\end{tabular}


Table 2. Regional Agreements negotiated under the Convention of Migratory Species (CMS).

\begin{tabular}{|c|c|c|c|c|}
\hline Convention & Scope & Range States & $\begin{array}{l}\text { No. of } \\
\text { parties I } \\
\text { members }\end{array}$ & $\begin{array}{l}\text { Year of } \\
\text { entry into } \\
\text { force }\end{array}$ \\
\hline $\mathrm{AEWA}^{6}$ & 255 waterbird species & $\begin{array}{l}119 \text { Range States in Africa, } \\
\text { Europe including parts of } \\
\text { Canada, Central Asia and the } \\
\text { Middle East }\end{array}$ & 64 & 1999 \\
\hline $\mathrm{ACAP}^{7}$ & $\begin{array}{l}21 \text { species of albatrosses and } 7 \\
\text { species of petrels from the } \\
\text { Southern Hemisphere }\end{array}$ & $\begin{array}{l}25 \text { Range States in the South- } \\
\text { ern Hemisphere, including } \\
\text { South-Africa, Argentina and } \\
\text { New Zealand }\end{array}$ & 13 & 2004 \\
\hline ACсOBAMS $^{8}$ & $\begin{array}{l}\text { Small cetaceans: } \\
\text { All cetaceans that occur in the } \\
\text { Black Sea, Mediterranean Sea } \\
\text { and contiguous area of the } \\
\text { Atlantic Ocean west of the } \\
\text { Straits of Gibraltar }\end{array}$ & $\begin{array}{l}29 \text { Range States that covers } \\
\text { the Black Sea, Mediterranean } \\
\text { Sea and the Atlantic coasts of } \\
\text { North Morocco and South } \\
\text { Portugal }\end{array}$ & 21 & 2001 \\
\hline ASCOBANS $^{9}$ & $\begin{array}{l}\text { Small cetaceans: } \\
\text { All species, subspecies or } \\
\text { population of toothed whales } \\
\text { (Odontoceti) in the Baltic Sea } \\
\text { and North Sea, with the excep- } \\
\text { tion of the Sperm whale }\end{array}$ & $\begin{array}{l}18 \text { Range States around the } \\
\text { shores of the Baltic and North } \\
\text { Seas }\end{array}$ & 10 & 1994 \\
\hline EUROBATS $^{10}$ & $\begin{array}{l}45 \text { bat species } \\
\text { European populations of Chi- } \\
\text { roptera (Rhinolophidae, Ves- } \\
\text { pertilionidae and Tadarida } \\
\text { teniotis) }\end{array}$ & $\begin{array}{l}49 \text { Range States in Europe, } \\
\text { including the European Com- } \\
\text { munity }\end{array}$ & 31 & 1994 \\
\hline $\begin{array}{l}\text { Wadden Sea } \\
\text { Agreement }^{11}\end{array}$ & $\begin{array}{l}\text { The common seal (Phoca } \\
\text { vitulina vitulina) occurring in the } \\
\text { Wadden Sea }\end{array}$ & $\begin{array}{l}3 \text { Range States (Netherlands, } \\
\text { Germany and Denmark) }\end{array}$ & 3 & 1991 \\
\hline $\begin{array}{l}\text { Gorilla }{ }^{12} \text { Agree- } \\
\text { ment }\end{array}$ & $\begin{array}{l}\text { All species of gorilla in their } \\
\text { distribution area in Africa }\end{array}$ & $\begin{array}{l}10 \text { Range States in Africa (e.g. } \\
\text { Angola, Cameroon and Re- } \\
\text { public of Congo) }\end{array}$ & - & 2008 \\
\hline
\end{tabular}

The biodiversity cluster is outlined in more detail in Figure 3. The figure shows that under the conventions a number of complementary approaches (species, genetic resources and/or ecosystem-based) and operational instruments (e.g. programmes of work, trade permits and certificates, multilateral system for access and benefit-sharing, regional agreements, site listings, funds) have been developed (SCBD 2005).

\footnotetext{
${ }^{6}$ African-Eurasian Waterbird Agreement

${ }^{7}$ Agreement on the Conservation of Albatrosses and Petrels

${ }^{8}$ Agreement on the Conservation of Cetaceans of the Black Sea and Contiguous Atlantic Area

${ }^{9}$ Agreement on the Conservation of Small Cetaceans of the Baltic, North East Atlantic, Irish and North Seas

${ }^{10}$ Agreement on the Conservation of Populations of European Bats

${ }^{11}$ Agreement on the Conservation of Seals in the Wadden Sea

${ }^{12}$ Agreement on the Conservation of Gorillas and Their Habitats
} 


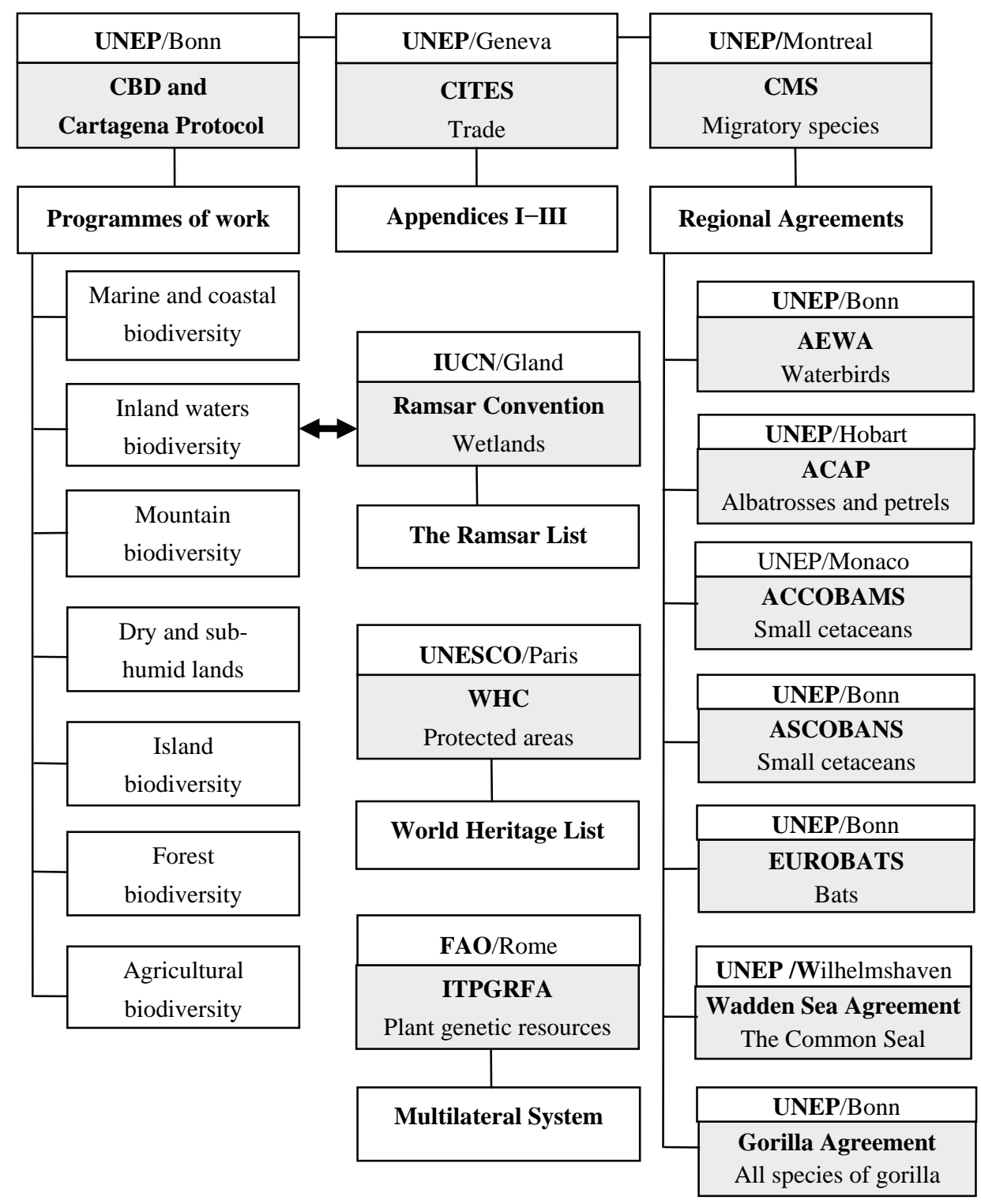

Figure 3. The three UNEP-administered MEAs (CBD, CITES and CMS) constitute a central part of the biodiversity cluster. The CBD differs from other MEAs within the biodiversity cluster by seeking to achieve a fully integrated approach to conservation (in situ as well as ex situ conservation) and by focusing strongly on sustainable use and equitable sharing of benefits. Much of the work of the CBD is implemented through the seven thematic programmes of work. CITES is the only MEA in the biodiversity cluster that regulates international trade and lists species in three appendices that vary according to the degree of the controls that apply to the trade. Migratory species are protected under the CMS mainly through the adoption of regional agreements and MoUs. The Ramsar Convention covers all aspects of wetland and water resource conservation and wise use and supports the CBD programme of work on inland water biodiversity. 


\subsection{MEAs in the proposed biodiversity cluster}

\subsubsection{Convention on Biological Diversity}

Following a decision from UNEP's Governing Council in 1987, a preparation and negotiation process for the CBD was started and finally the convention text was adopted in Nairobi on 22 May 1992. The convention was opened for signature in Rio in June 1992 and entered into force in December 1993. The objective of the convention is the conservation and sustainable use of biodiversity, and the fair and equitable sharing of the benefits arising from genetic resources. The CBD is the only convention that addresses all levels of biodiversity: species, ecosystems and genetic resources. In 2000, the CBD COP adopted the Cartagena Protocol on Biosafety that seeks to protect biological diversity from the potential risks posed by living modified organisms resulting from modern biotechnology.

The CBD has developed seven thematic programmes of work that set the overall goals and policies to guide future work. Specific actions for implementation are to be developed by the parties. The CBD does not include a traditional regulatory approach (no lists, a descriptive annex on components of biodiversity and no protected areas) and there is no specific mechanism to assess the degree of implementation by the parties. In 2002, the CBD COP adopted a strategic plan that includes the commitment of the parties "to achieve by 2010 a significant reduction of the current rate of biodiversity loss at the global, regional and national level".

In previous years the CBD has focused on developing work programmes, guidelines and co-operation mechanisms that have served to increase the number of meetings every year. The emphasis of the convention has recently shifted to strengthening the implementation of the decisions taken by the COP.

\subsubsection{Convention on International Trade in Endangered Species}

The Convention on International Trade in Endangered Species (CITES) was adopted in Washington D.C. in 1973 at a Diplomatic Conference and entered into force in July 1975 . The convention aims to ensure that international trade in specimens of wild animals and plants does not threaten their survival. CITES is the only convention in the biodiversity cluster that regulates international trade of threatened species. CITES is widely considered to be among the most effective global environmental regimes.

CITES functions by subjecting international trade in specimens of selected species to certain controls. The species covered by CITES are listed in three appendices:

- Appendix I lists species that are threatened with extinction and are not to be traded for commercial purposes. 
- Appendix II lists species that are not necessarily threatened now with extinction, but may become so unless trade is closely controlled. The species may be traded, but they require an export permit or re-export certificate from a national management authority.

- Appendix III is a list of species included at the request of a party that already regulates trade in the species and that needs the co-operation of the other parties in the control of international trade.

Parties can submit proposals to amend Appendices I and II at COP meetings. Amendments require a two-thirds majority of those parties present and voting. However, species may be added and also removed by the same party from Appendix III at any time. The most significant weakness of CITES is that it allows parties to enter a reservation to a specific Appendix I or II listing. A reservation makes that party in effect a non-party with regard to that particular species (Chasek et al. 2006).

The most effective tool of CITES is the use of temporary trade suspensions to address non-compliance. A recommendation to suspend trade in specimens of CITES-listed species is adopted by the COP or the Standing Committee when there is sufficient evidence of non-compliance. The trade suspensions can be different in scope and can include 1) all trade in specimens of CITES species; 2) all commercial trade in CITES species; or 3) all trade in specimens of a particular species. The temporary trade suspensions are withdrawn immediately upon a country”s return to compliance.

\subsubsection{Convention on Migratory Species}

The Convention on Migratory Species (CMS) was concluded under the aegis of UNEP in Bonn in 1979. This event was the culmination of several years of efforts and international consultations steered by Germany and supported by the IUCN Environmental Law Centre. The convention entered into force in November 1983. The objective of the convention is the conservation of terrestrial, marine and avian migratory species throughout their range. In 2002, the CBD recognized the CMS as the key lead partner for conservation of migratory species.

Migratory species under the convention are listed in two appendices:

- Appendix I lists migratory species that are threatened with extinct-tion. Parties need to strictly protect these animals, conserve or restore their habitats, mitigate obstacles to migration and control other factors that might endanger them.

- Appendix II lists species that would significantly benefit from international co-operation. The convention encourages range states to conclude global or regional agreements that may range from legallybinding treaties (agreements) to less formal instruments, such as MoUs. 
The CMS is implemented to a large extent through seven regional agreements and several MoUs that have been concluded to date under the auspices of CMS (Annex 1). A particular strength of the CMS is that each agreement can be tailored to meet conservation needs throughout a species migratory range, and to provide a comprehensive framework for transboundary co-operation among range states (SCBD 2005). However, the continued growth in the number of regional agreements and MoUs, as well as the increase in the number of CMS Parties, has recently led to the concern that the uncontrolled development of the convention might lead to a lack of coherence within the CMS family. In 2008, the CMS COP9 launched an intersessional process to review the future shape of the $\mathrm{CMS}^{13}$. An ad hoc working group has been established to consider possibilities for delivering a more integrated conservation programme, developing new agreements, strengthening the position of the CMS in various regions of the world, ensuring a sound science base and strengthening cooperation with other international organizations.

\subsubsection{Ramsar Convention on Wetlands}

The Ramsar Convention aims to ensure the conservation and wise use of all wetlands through local, regional and national actions and international co-operation. The Ramsar Convention was adopted in 1971 in Ramsar, Iran, and entered into force in December 1975. The original emphasis of the convention was on the conservation and wise use of wetlands, primarily to provide habitat for waterbirds. Over the years the convention has broadened its scope to cover all aspects of wetland and water resource conservation and wise use, including freshwater and saline inland waters and marine waters up to a depth of 6 meters. The CBD has recognised the Ramsar Convention on Wetlands as the lead implementing partner on wetlands for the $\mathrm{CBD}^{14}$. The Ramsar Convention is co-located in the IUCN headquarters and is the only non-UN convention in the biodiversity cluster.

The convention includes four main obligations that the parties have agreed to by joining. The List of Wetlands of International Importance (the Ramsar List) is the main instrument through which the convention works. Parties must designate at least one wetland for inclusion on the Ramsar List and to promote its conservation and wise use. Presently, more than 1822 Ramsar sites have been designated, covering 1.70 million $\mathrm{km}^{2}$. Other obligations include establishing nature reserves in wetlands (whether or not they are included on the Ramsar List), including wetland conservation considerations in their national land-use planning and consulting with other parties about implementation of the convention, espe-

\footnotetext{
${ }^{13} \mathrm{UNEP} / \mathrm{CMS} /$ Resolution 9.13

${ }^{14} \mathrm{UNEP} / \mathrm{CBD} / \mathrm{COP} / 3 / 21$.
} 
cially in regard to transfrontier wetlands, shared water systems, and shared species.

The Montreux Record is the principal tool of the Convention for highlighting specific Ramsar sites that are facing immediate challenges and that are in need of priority conservation attention. There are currently 55 sites listed in the Montreux Record. The Montreux Record was established in 1990 by Recommendation 4.8.

Ramsar works closely with non-governmental organizations, five of which have been confirmed the formal status of International Organization Partners of the Convention (IOP): BirdLife International, IUCN, Wetlands International, the World Wide Fund for Nature (WWF) and the International Water Management Institute (IWMI). The IOPs provide scientific and technical advice, field-level implementation assistance, financial support, and regularly participate in all meetings organized by Ramsar, either as observers (COP, Standing Committee) or members (Scientific and Technical Review Panel, STRP).

\subsubsection{World Heritage Convention}

The World Heritage Convention (WHC) was drafted in the early 1970s by experts from IUCN, the International Council of Monuments and Sites (ICOMOS) and the United Nations Scientific and Cultural Organization (UNESCO). The convention was adopted by the General Conference of UNESCO in November 1972 and entered into force in 1975. The primary mission of the WHC is to identify and conserve the world's cultural and natural heritage, by drawing up a list of sites whose outstanding values should be preserved for all humanity, and to ensure their protection through a closer co-operation among nations.

The WHC defines the type of natural or cultural sites which can be considered for inclusion on the World Heritage List. Out of ten selection criteria, those that meet criteria (ix) and (x) indicate sites where biodiversity conservation is likely to be of particular significance ${ }^{15}$. The World Heritage List currently consists of 878 sites that include 174 natural and 25 mixed natural and cultural sites. Protection of a site can include sustainable use, where ecologically and culturally appropriate. The World Heritage Committee can inscribe on the List of World Heritage in Danger endangered properties that require "major operations (...) and for which assistance has been requested”.

\footnotetext{
${ }^{15}$ Criteria (ix): be outstanding examples representing significant ongoing ecological and biological processes in the evolution and development of terrestrial, fresh water, coastal and marine ecosystems and communities of plants and animals.

Criteria (x): contain the most important and significant natural habitats for in-situ conservation of biological diversity, including those containing threatened species of outstanding universal value from the point of view of science or conservation.
} 


\subsubsection{International Treaty on Plant Genetic Resources}

After 20 years of negotiations the International Treaty on Plant Genetic Resources for Food and Agriculture (ITPGRFA) was adopted under the aegis of the Food and Agriculture Organization of the United Nations (FAO) in November 2001 and entered into force in March 2004. The convention aims to ensure the conservation and sustainable use of plant genetic resources for food and agriculture (PGRFA) and the fair and equitable sharing of the benefits arising out of their use, in harmony with the CBD, for sustainable agriculture and food security.

The treaty establishes a Multilateral System of Access and BenefitSharing (MLS) for 64 key food crops and 29 forage species (the genera and species are listed in Annex 1). Parties need to make the data on species' genetic diversity and related information stored in gene banks accessible to all. By accessing plant genetic materials through the MLS one agrees to freely share any new product development with others for further research. However, it is also possible to not share the product development by paying a percentage of any commercial benefits derived from the research into a common fund to support conservation and further development of agriculture in the developing countries.

The convention also aims to recognize and protect Farmers" Rights the rights of farmers to access and use plant genetic resources for food and agriculture and to be rewarded and respected as managers and custodians of these resources. The treaty gives governments the responsibility for implementing Farmers' Rights, and lists measures that could be taken to protect and promote these rights. These include, inter alia, the protection of traditional knowledge relevant to plant genetic resources for food and agriculture, as well as the right to equitably participate in sharing benefits arising from the utilization of plant genetic resources for food and agriculture.

\subsection{Other MEAs and related processes that are linked to biodiversity}

\subsubsection{Convention to Combat Desertification}

The United Nations Convention to Combat Desertification (UNCCD) was adopted in Paris in June 1994 and entered into force in December 1996. The objective of the convention is to combat desertification and mitigate the effects of drought in countries experiencing serious drought and/or desertification, particularly in Africa. The convention is the only internationally legally binding framework that addresses desertification. The UNCCD contains provisions that also address biodiversity, climate change, forests, and freshwater resources, as well as other issues (Chasek et al. 2006). The UNCCD is linked to biodiversity through its strong fo- 
cus on conservation and sustainable use of terrestrial ecosystems in dry and sub-humid areas.

National Action Programmes (NAPs) are one of the key instruments in the implementation of the convention. NAPs are developed through a participatory approach by involving local communities who determine the measures to be taken to combat desertification in specific ecosystems. They are strengthened by Sub-Regional Action Programmes (SRAP) and Regional Action Plans (RAP).

In 2007, the convention adopted a 10-year strategic plan and framework (2008-2018) to enhance the implementation of the convention ${ }^{16}$. It sets first-ever time-bound "strategic objectives" for UNCCD stakeholders.

\subsubsection{International Convention for the Regulation of Whaling}

The International Convention for the Regulation of Whaling (ICRW) was signed in Washington in December 1946 and entered into force in November 1948. The purpose of the ICRW, as stated in the convention, is to "provide for the proper conservation of whale stocks and thus make possible the orderly development of the whaling industry". Initially, the convention was not a prohibition regime but a club of whaling nations designed to manage the catch. The convention prohibited killing certain species with much reduced populations, set quotas and minimum size for whales that were caught commercially, and regulated whaling seasons. The ICRW has, in practice, gradually evolved into a whale protection regime.

The International Whaling Commission (IWC) is an international body set up by the terms of the convention. In 1982 the IWC adopted a five-year ban on all commercial whaling of large whales. The ban is still in force, although the convention allows scientific whaling. The whale protection regime has been further strengthened in 1994 by the adoption of a Southern Ocean Whale Sanctuary that prohibits whaling in all waters below 40 degrees south latitude (Chasek et al. 2006). Norway has lodged an objection to the commercial whaling ban, and Iceland has made a reservation of similar purpose when re-adhering to the Convention. Both countries have conducted commercial whaling outside the control of the IWC (Nordic... 2006). Japan, on the other hand, has conducted whaling with a special permit under the provisions of the convention.

The IWC members do not agree whether the convention includes small whales, for example, those which are covered by CITES. Beginning in 1979, and affirmed recently by resolution 11.4 (CoP12), the position of CITES has been to assure that no conflict exists between the two treaties and to support the IWC ban on all commercial whaling by maintaining Appendix I listing for stocks of all large whale species, except the West

\footnotetext{
${ }^{16}$ UNCCD decision 3/COP8
} 
Greenland population of the Minke whale. The CMS Convention includes 39 species of small cetaceans in its Appendix II. Following this, two regional agreements - ASCOBANS and ACCOBAMS - have been concluded under the CMS Convention that cover small cetaceans in the Baltic and North Seas, and the Black and Mediterranean Seas (Gillespie 2001).

\subsubsection{United Nations Forum on Forests}

Countries have been discussing international forest policy issues within the United Nations system since 1945. However, states have not been able to agree on a legally binding treaty concerning the conservation and sustainable use of forests, instead, several non-legally binding agreements on forests have been created. In 1992, in Rio de Janeiro states adopted "the Forest Principles", a non-legally binding document that makes several recommendations for the management, conservation and sustainable management of all types of forests. During 1996-2000, the Intergovernmental Panel on Forests (IPF) and the Intergovernmental Forum on Forests (IFF) produced 270 proposals for action (known collectively as the IPF/IFF Proposals for Action) to further develop, implement and coordinate policies on sustainable forest management.

In 2000, the United Nations Forum on Forest (UNFF) was established by the UN Economic and Social Council (ECOSOC) as a central intergovernmental forum to deliberate international policy on forests. The UNFF adopted at its seventh session in 2007 a Non-Legally Binding Instrument on All Types of Forests (NLBI) ${ }^{17}$, which was further adopted by the General Assembly in its $62^{\text {nd }}$ Session ${ }^{18}$. The instrument is expected to have a major impact on international co-operation and national action to reduce deforestation, prevent forest degradation, promote sustainable livelihoods and reduce poverty. In the next session (UNFF-8) held in New York in spring 2009, states will address, inter alia, forests and biodiversity, including protected areas. In addition, states will consider adopting a decision on a voluntary global financial mechanism, a portfolio approach and a forest financing framework aiming at mobilizing new and additional resources for the implementation of sustainable forest management.

In 2001, A Collaborative Partnership on Forests (CPF) was also established to support the work of the UNFF and to foster increased co-operation and co-ordination on forests ${ }^{19}$. However, co-operation between the organizations has not significantly increased since the establishment of the CPF.

\footnotetext{
${ }^{17}$ UN doc. E/CN.18/2007/8 (UNFF Report of the seventh session)

${ }^{18} \mathrm{UN}$ doc. A/C.2/62/L.5

${ }^{19}$ The CPF is currently composed of 14 international organization members: Centre for International Forestry Research (CIFOR), FAO, International Tropical Timber Organization (ITTO), International Union of Forestry Research Organization (IUFRO), Secretariat of the CBD, Secretariat of the Global Environment Facility (GEF), Secretariat of the UNCCD, Secretariat of UNFF, Secretariat of the United Nations Framework Convention on Climate Change (UNFCCC), United Nations Development Program (UNDP), UNEP, World Agroforestry Centre (ICRAF), World Bank and IUCN.
} 


\section{Governance at what levels?}

This section will discuss the different levels of governance of the MEAs in the biodiversity cluster. The first subsection looks at country-driven processes, while the second subsection deals with the secretariat level. Subsection 4.3 deals with administrative and conference services. Last, the role of organizations that play an important role in the co-ordination of the biodiversity cluster is discussed.

\subsection{Country-driven processes}

As a general rule, a conference or meeting of the parties (COP, MOP) to the agreement serves as the governing and supreme decision-making body of the MEA. It may also have a different term, for example, the highest organ for the ITPGRFA is called the Governing Body. The supreme decision-making bodies of the MEAs have an independent legal character and are not subsidiaries of the General Assembly or of any other body. The supreme decisionmaking bodies of the biodiversity-related MEAs are listed in Table 5.

The functions of the supreme decision-making body are set out in each MEA. Generally, the main function is to continuously review and evaluate the implementation of the MEA and take decisions to further enhance implementation. Some of the tasks are expressly provided for in the provision establishing the COP as well as in other provisions on specific issues. Depending on the MEA, the tasks include, inter alia, adopting rules of procedure and financial rules, establishing subsidiary bodies, adopting decisions, and evaluating periodically the effectiveness of the MEA (UNEP et al. 2007).

Cooperating with other MEAs and organizations is also an important function of the supreme decision-making bodies (UNEP et al. 2007). However, the supreme decision-making bodies of the MEAs in the biodiversity cluster have limited mutual co-operation at the secretariat level. Possibilities for enhancing co-operation and co-ordination among the contracting parties of the MEAs in the biodiversity cluster is discussed below (see Section 4.2.2).

The Conferences of the Parties (COPs) of CBD, CITES, CMS, Ramsar and UNCCD and the Meetings of the Parties (MOPs) of AEWA, ACAP, ACCOBAMS, ASCOBANS and EUROBATS function in a similar manner. They are held every two to four years depending on the convention. Each Party may send a delegation to the COP/MOP to discuss the issues under consideration and all Parties have the equal right to vote. Decision-making must be accomplished by consensus among Parties of the CBD because the 
voting rules have not been agreed upon. In the other COPs/MOPs voting is a more or less regular feature.

The structure of the WHC differs from the MEAs in the biodiversity cluster: instead of a COP it has a General Assembly of States Parties, which meets during the UNESCO General Conference. The World Heritage Committee is responsible for the implementation of the convention and its members are elected at the General Assembly. The Committee meets once a year, and consists of representatives from 21 of the States Parties. A Committee member's term of office is for six years.

Table 3. Supreme decision-making bodies of the MEAs in the biodiversity cluster and other MEAs and related processes linked to biodiversity.

\begin{tabular}{|c|c|c|c|}
\hline Supreme decision-making body & Frequency of meetings & Duration & Next Session \\
\hline \multicolumn{4}{|l|}{ CBD } \\
\hline \multirow{2}{*}{$\begin{array}{l}\text { COP: Conference of Parties to the } \\
\text { Convention on Biological Diversity }\end{array}$} & \multirow[t]{2}{*}{ Every two years } & \multirow[t]{2}{*}{2 weeks } & COP10 (18-29.11.2010) \\
\hline & & & Nagoya, Japan \\
\hline \multirow{4}{*}{$\begin{array}{l}\text { COP-MOP: The Conference of the } \\
\text { Parties to the Convention on Biological } \\
\text { Diversity serving as the meeting of the } \\
\text { Parties to the Protocol }\end{array}$} & \multirow{4}{*}{$\begin{array}{l}\text { At least once every } \\
\text { two years }\end{array}$} & \multirow[t]{4}{*}{1 week } & COP-MOP4 \\
\hline & & & $(11-15.11 .2010)$ \\
\hline & & & Nagoya, Japan \\
\hline & & & \\
\hline \multicolumn{4}{|l|}{ CITES } \\
\hline \multirow[t]{2}{*}{ COP: Conference of the Parties } & \multirow{3}{*}{$\begin{array}{l}\text { Every two to three } \\
\text { years. }\end{array}$} & \multirow[t]{2}{*}{2 weeks } & CoP15 (16-28.1.2010) \\
\hline & & & Doha, Quatar \\
\hline \multicolumn{3}{|l|}{ CMS } & \\
\hline COP: Conference of the Parties to CMS & $\begin{array}{l}\text { Every two to three } \\
\text { years. }\end{array}$ & 1 week & COP10 (in 2011) \\
\hline \multicolumn{4}{|l|}{ AEWA } \\
\hline MOP: Meeting of the Parties & Every three years & 1 week & MOP5 (in 2012) France \\
\hline \multicolumn{4}{|l|}{ ACAP } \\
\hline \multirow[t]{2}{*}{ MoP: Meeting of the Parties } & \multirow[t]{2}{*}{ Every two years } & \multirow[t]{2}{*}{1 week } & MoP2 (27.4-1.5.2009) \\
\hline & & & Bergen, Norway \\
\hline \multicolumn{4}{|l|}{ ACCOBAMS } \\
\hline MOP: Meeting of the Parties & $\begin{array}{l}\text { Every two to three } \\
\text { years }\end{array}$ & 1 week & MOP4 (in 2010), Monaco \\
\hline \multicolumn{4}{|l|}{ ASCOBANS } \\
\hline MOP: Meeting of the Parties & Every three years & $3-4$ days & MOP6 (in 2009) \\
\hline \multicolumn{4}{|l|}{ EUROBATS } \\
\hline MoP: Meeting of Parties & $\begin{array}{l}\text { Every three to four } \\
\text { years }\end{array}$ & 3 days & MoP6 (in 2009) \\
\hline \multicolumn{4}{|l|}{ Ramsar } \\
\hline \multirow{2}{*}{$\begin{array}{l}\text { COP: Conference of the Contracting } \\
\text { parties to the Convention on Wetlands }\end{array}$} & \multirow[t]{2}{*}{ Every three years. } & \multirow[t]{2}{*}{1 week } & COP 11 (in 2012) \\
\hline & & & Romania \\
\hline \multicolumn{4}{|l|}{ WHC } \\
\hline Session of the World Heritage Committee & Annually & 7-9 days & $\begin{array}{l}\text { 33nd session } \\
\text { (22-30.6.2009) Seville, Spain }\end{array}$ \\
\hline ITPGRFA & & & \\
\hline GB: The Governing Body of the Interna- & At least once every & 1 week & GB-3 (1-5.6.2009) \\
\hline $\begin{array}{l}\text { tional Treaty on Plant Genetic Resources } \\
\text { for Food and Agriculture }\end{array}$ & two years & & Tunis, Tunisia \\
\hline UNCCD & & & \\
\hline COP: Conference of the Parties of the & Every two years. & 2 weeks & COP9 (21.9-2.10.2009) \\
\hline $\begin{array}{l}\text { United Nations Convention to Combat } \\
\text { Desertification }\end{array}$ & & & Buenos Aires, Argentina \\
\hline ICRW & & & \\
\hline Annual Meeting of the International & Annually & 1 week & IWC-61 (22-26.6.2009) \\
\hline Whaling Commission & & & Madeira, Portugal \\
\hline
\end{tabular}




\subsubsection{Meetings of the supreme decision-making bodies}

The supreme decision-making bodies of the MEAs of the biodiversity cluster do not meet at a permanent location. They meet periodically in locations that are determined from one meeting to the next, based on prospective host country proposals and invitations. A certain concentration of meetings may occur, usually at the location of the seat of the secretariat or at venues located in UN regional hubs, such as Geneva and Nairobi. There is a strong upward trend in the weeks spent on negotiations as shown in Figure 4.

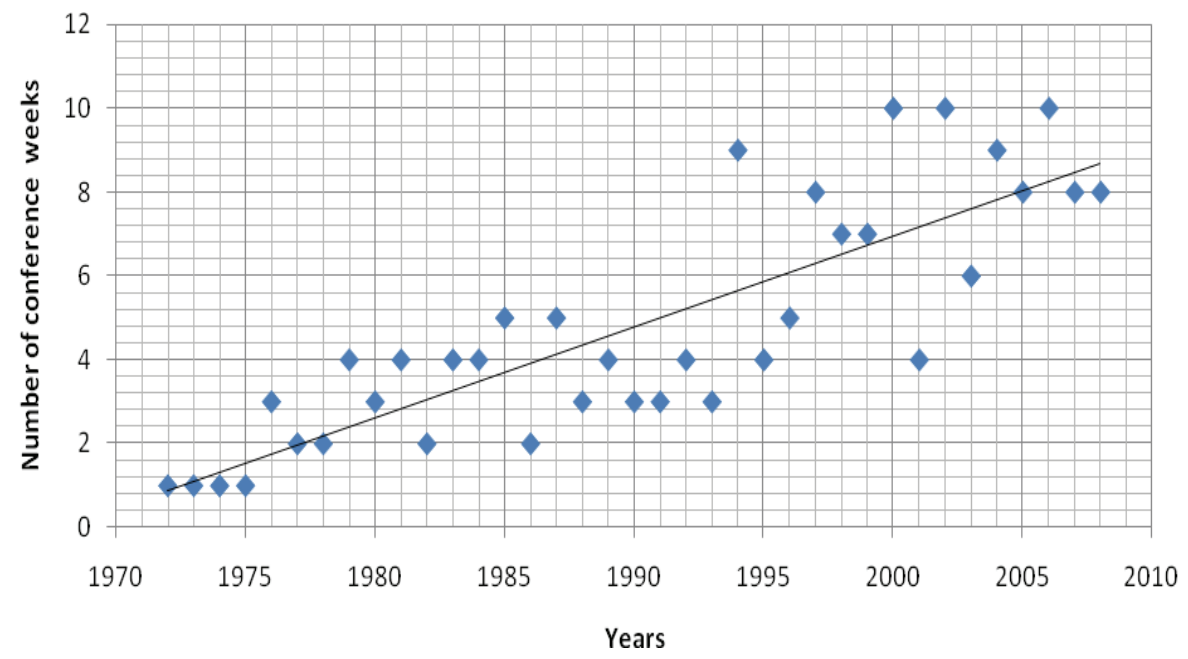

Figure 4. The number of weeks spent on intergovernmental negotiations among the six MEAs in the biodiversity cluster (including the CMS Regional Agreements) has grown rapidly after the 1972 Stockholm Conference and the 1992 Rio Conference. The graph shows only the total duration of the meetings of the supreme decision-making bodies, while the numerous meetings of working groups and standing committees, as well as other meetings, are not displayed.

There are two main options for coordinating and streamlining COP meetings of MEAs in the biodiversity cluster that include:

- Simultaneous meetings - arranging meetings jointly or in parallel

- Back-to-back meetings - arranging meetings one following the other sequentially in the same location

The benefits of coordinating and streamlining the COP meetings could include, inter alia, reduced costs, frequency and duration of the meetings, reduced travel costs if a significant overlap of government representatives exists, and reduced inconsistencies and overlaps in decision-making. The three MEAs in the chemicals and waste cluster are arranging a simultaneous extraordinary meeting (Box 1). In addition, it is possible to create a permanent location for the supreme decision-making bodies of the MEAs in the biodiversity cluster (Box 2). 


\section{BOX 1}

The simultaneous extraordinary meetings of the COPs (PIC, POPs and Basel)

Convening simultaneous extraordinary meetings of the COPs to the Basel, Rotterdam and Stockholm Conventions was one of the last items agreed upon at the AHJWG meetings. The simultaneous extraordinary meetings will be held and governed by the conventions' specific rules and procedures. In practical terms, the Parties to the three conventions would meet at the same venue at the same time, but take decisions individually. It is proposed that such simultaneous extraordinary COP meetings be held back-to-back to the 11th special session of the UNEP Governing Council/Global Ministerial Environment Forum in 2010.

\section{BOX 2}

\section{The WTO model}

A permanent location would permit the development of an infrastructure to support the supreme decision-making bodies, including the creation of specialized missions from the member states. The advantages of a single location and permanent missions can be clarified by the example of the World Trade Organization (WTO). The missions have become an organizational structure of the WTO and explain how the organization manages to cover a wide agenda with a relatively small Secretariat (von Moltke 2005). A permanent location would benefit developing countries, since it would enable governments to build adequately staffed environmental desks within their foreign services (Holst 1999).

The prospects for arranging simultaneous or back-to-back meetings among the supreme decision-making bodies in the biodiversity cluster appears remote. Convening back-to-back meetings would result in long and heavy negotiations; for example, in the case of just two MEAs (the CBD and CITES COPs) the combined duration of the meetings would add up to five weeks. Since the host country usually covers most or all of the costs of the meetings, developing countries would also have difficulties hosting these meetings. For example, the final bill for COP8 in $\mathrm{Cu}-$ ritiba, Brazil, amounted to some USD 10 million. Simultaneous meetings would cause an increase in the number of participants attending a conference site.

By contrast, within the MEAs it is a common practice that meetings are arranged back-to-back. An information note provided by the CBD Secretariat shows there is a pattern of pairing meetings under the CBD, for example, the COP-MOP meetings of the Cartagena Protocol are held back-to- 
back with the CBD COP meetings (UNEP 2008a). Similarly, meetings of the Working Group on Access and Benefit-Sharing (ABS) and of the Working Group on Article 8(j) are usually held back-to-back, and the meetings of the Subsidiary Body on Scientific, Technical and Technological Advice (SBSTTA) are paired with the meetings of the Working Group on Protected Areas. According to the Secretariat of the CBD, this has helped to streamline the organizational and logistics process and has contributed to a savings of approximately USD 100,000-150,000 (UNEP 2008a).

It is important to note that the CITES, CMS, Ramsar, AEWA and EUROBATS conventions and agreements have established standing committees that consist of a restricted number of parties which meet between the COP sessions (Table 4). The standing committees represent the authority of the COPs intersessionally.

Table 4. The Standing Committees of the MEAs in the biodiversity cluster.

\begin{tabular}{|c|c|c|c|c|}
\hline Standing committee & Established & Frequency of meetings & Duration & Size \\
\hline \multicolumn{5}{|l|}{ Ramsar } \\
\hline $\begin{array}{l}\text { The Ramsar Standing } \\
\text { Committee }\end{array}$ & $\begin{array}{l}\text { In } 1987 \\
\text { (Resolution 3.3 ) }\end{array}$ & $\begin{array}{l}\text { At least once every } \\
\text { year }\end{array}$ & $1-5$ days & 15 Parties \\
\hline \multicolumn{5}{|l|}{ CMS } \\
\hline $\begin{array}{l}\text { The Standing Committee of } \\
\text { the CMS }\end{array}$ & $\begin{array}{l}\text { In } 1985 \\
\text { (Resolution } 1.1 \text { ) }\end{array}$ & $\begin{array}{l}\text { At least once every } \\
\text { year }\end{array}$ & $1-5$ days & 10 Parties \\
\hline \multicolumn{5}{|l|}{ AEWA } \\
\hline $\begin{array}{l}\text { AEWA Standing } \\
\text { Committee }\end{array}$ & $\begin{array}{l}\text { In } 2002 \\
\text { (Resolution 2.6) }\end{array}$ & $\begin{array}{l}\text { (every one to two } \\
\text { years }\end{array}$ & 2 days & 7 Parties \\
\hline \multicolumn{5}{|l|}{ EUROBATS } \\
\hline & $\begin{array}{l}\text { In } 2006 \\
\text { (Resolution 5.8) }\end{array}$ & $\begin{array}{l}\text { At least once every } \\
\text { year }\end{array}$ & 1 day & 7 Parties \\
\hline CITES & In 1979 & $\begin{array}{l}\text { At least once every } \\
\text { year }\end{array}$ & $1-5$ days & 15 parties \\
\hline
\end{tabular}

\section{Recommendation 1}

While is seems impossible to streamline the meetings of the supreme decision-making bodies, the practice of arranging back-to-back meetings of the different bodes within the MEAs should be further encouraged when this would bring benefits.

\section{Recommendation 2}

As a consequence of the proliferation of the MEAs and the growing multitude of issues they deal with, the time spent on inter-governmental negotiations has continuously increased. The continuous development of work programmes, guidelines and co-operation mechanisms that are often at least partly overlapping and not streamlined has served to increase difficulties in priority setting and has created ever-growing deficiencies in implementation. The overgrown agendas of the meetings of the supreme deci- 
sion-making bodies should be reduced by focusing more clearly on the most relevant issues. This could enable a gradual shortening of the duration of the meetings and also help in setting priorities for implementation.

\subsection{Secretariat level}

MEAs normally make provisions for a secretariat. The functions of a secretariat may vary, but it plays an essential role in ensuring the effective functioning of the supreme decision-making body and its subsidiary bodies. The mandates of the secretariats have been spelled out in articles to the respective conventions and are given in more detail in their rules for procedure (Annex 2).

The legal status of the secretariat is quite different from that of the supreme decision-making body. The legal characteristics of the supreme decision-making bodies with their extensive powers to make binding decisions in relation to all internal matters, such as establishing subsidiary bodies, adopting rules of procedure and directing the work of the subsidiary bodies and the secretariat, and amending an MEA, must be distinguished at the very outset from the legal status of the secretariats, which have no such decision-making powers (Kurukulasuriya 2008). If the supreme decision-making body (usually the COP) can be likened to the legislative arm of the convention then the secretariat is the executive (Johnston 1999). When compared to inter-governmental organisations such as FAO or the World Bank, the secretariats' formal autonomy as stated in its mandate is rather limited (Siebenhüner 2007).

Some of the most common tasks of the secretariats include arranging and giving logistical support to the meetings, as well as collecting and disseminating information. The secretariats may also conduct studies, and prepare agendas and reports (UNEP et al. 2007). Helping the parties, particularly developing country parties, is an essential function of a secretariat (Johnston 1999). The secretariats also provide continuity and a forum through which information exchange can occur (Johnston 1999).

The governing body may, and normally does, assign additional tasks to the secretariat. Often these tasks relate to the various international activities required to meet the objectives of the conventions (UNEP et al. 2007). An important function of the secretariat is to facilitate cooperation and co-ordination as required with other MEAs and international organisations, as described in detail below.

\subsubsection{The location of the Secretariats}

The MEAs in the biodiversity cluster locate or make use of the secretariats in the existing intergovernmental organizations (IGOs). UNEP provides the Secretariat for CBD, CITES and CMS, as well as for AEWA, 
ACAP, ACCOBAMS, ASCOBANS, EUROBATS and the Gorilla Agreement. Whereas, the Secretariat of ITPGRFA is administered by FAO and the Ramsar Secretariat is provided by IUCN. The MEAs in the biodiversity cluster are located around the world (Table 5). The number of staff of the six MEAs in the biodiversity cluster is around 180 .

Although the CMS Secretariat is located in Bonn, several agreements negotiated under the auspices of the CMS have an independent Secretariat, co-located either in Bonn (EUROBATS and AEWA) or elsewhere (ACAP, ACCOBAMS and Wadden Sea Agreement). The secretariat functions of the newly negotiated Gorilla Agreement, as well as the MoUs, are provided by the CMS Secretariat, with the exception of the IOSEA Marine Turtle MoU, which is independent and co-located with the UNEP Regional Office for Asia and the Pacific (UNEP/ROAP) in Bangkok, Thailand.

Table 5. Location and host of the Secretariats of the MEAs in the biodiversity cluster and other MEAs and related processes linked to biodiversity.

\begin{tabular}{llll}
\hline MEA & Location & $\begin{array}{l}\text { Host } \\
\text { institution }\end{array}$ & No. of staff \\
\hline CBD & Montréal, Canada & UNEP & 76 \\
CITES & Geneva, Switzerland & UNEP & 28 \\
CMS & Bonn, Germany & UNEP & 18 \\
AEWA & Bonn (co-located) & UNEP & 4 \\
ACAP & Hobart, Australia & UNEP & 6 \\
ACCOBAMS & Monaco & UNEP & 3 \\
ASCOBANS & Bonn (CMS Secretariat) & UNEP & 2 \\
EUROBATS & Bonn (co-located) & UNEP & 2,5 \\
Wadden Sea Agreement & Wilhelmshaven, Germany & UNEP & 7 \\
Gorilla Agreement & Bonn (CMS Secretariat) & UNEP & - \\
Marine Turtles-IOSEA & Bangkok, Thailand & UNEP & 2 \\
Ramsar & Gland, Switzerland & IUCN & 19 \\
WHC & Paris, France & UNESCO & $?$ \\
ITPGRFA & Rome, Italy & FAO & 7 \\
UNCCD & Bonn, Germany & UN & 56 \\
ICRW & Cambridge, England & Independent & 17 \\
UNFF & New York, USA & UN & 10 \\
\hline
\end{tabular}

The financial implications for separate secretariats for the MEAs are significant. A recent report provided by the UN Joint Inspection Unit (Inomata 2008) shows that during 1992-2005 the unit cost of MEAs grew by a factor of 4.7, compared to 1.2 for conventions under the custody of UN agencies (ILO, FAO, IMO, IAEA and UNESCO). This is explained by the fact that new MEAs, often generated under the aegis of UNEP, have been established with separate secretariat functions. In contrast, the UN agencies' conventions are embedded in the administering organization and are more modest than those of independent secretariats.

There have been discussions as to the feasibility of co-locating the MEA secretariats. MEAs taking part in thematic clustering could benefit from joint secretariats. As illustrated above, the co-location of the MEA secretariats leads to efficiency gains. Co-located secretariats share facilities and personnel, which increases co-ordination of administrative pro- 
cedures (Oberthür 2002). It is important to note that the co-located secretariats of the MEAs in the chemicals and waste cluster have considered possibilities for enhancing synergies by arranging joint services for all three conventions (Box 3).

\section{BOX 3}

Joint services for the PIC, POPs and Basel Conventions

With the aim of improving the efficiency and delivery of services of the PIC, POPs and Basel Conventions, the AHJWG has provided recommendations for establishing joint services for the three conventions. The AHJWG suggests establishing a joint financial and administrative support service within the Secretariats of Geneva and preparing a proposal for joint audits of the accounts of the Secretariats. Other recommended actions include the organizing of a joint legal service, a joint information technology service and a joint information service. In addition, the AHJWG recommended developing a common arrangement for the staffing and financing of joint services (including shared posts).

The prospect for dramatic reorganization of the secretariats in the biodiversity cluster appears remote. In most cases, the co-location of the MEA secretariats is politically daunting because it is expected to create fierce competition between host countries (von Moltke 2001). In addition, host countries have invested a lot of political and financial resources in building the secretariats and are most likely not willing to easily sign away the secretariats.

It is important to highlight that the Ramsar Convention is looking at options to improve the capacity and operation of the Secretariat. In October 2008, the 10th meeting of the Ramsar COP established an ad hoc working group to consider possibilities for improving the current operations of the Secretariat and determine whether the Secretariat should be provided by UNEP, instead of IUCN ${ }^{20}$. Joining UNEP would bring various benefits and facilitate closer co-operation with other UNEPadministered MEAs (CBD, CITES and CMS) in the biodiversity cluster. The location of a UNEP-administered Ramsar Secretariat would presumably be the UNEP premises in Geneva; thereby, enabling co-location with the CITES Secretariat. A decision of two-thirds majority would be necessary to appoint another organization to carry out the Secretariat functions of the Ramsar Convention ${ }^{21}$.

Another feasible option is to co-locate smaller secretariats in the biodiversity cluster. However, experiences from the ASCOBANS Convention show that it is difficult to merge even small secretariats. During 1998

\footnotetext{
${ }^{20}$ Ramsar Resolution COP10 X.5.

${ }^{21}$ Article 8(1) of Ramsar.
} 
to 2006, ASCOBANS had an independent secretariat with a permanent staff of two. In December 2006, the 5th Meeting of the Parties to ASCOBANS decided to restructure the Agreement's bodies by merging the formerly independent secretariat with the co-located Secretariat of its mother convention (CMS). The merging of the secretariats was a result of long negotiations and only on a trial basis (EMG 2008).

As shown by the ASCOBANS case, the supreme decision-making bodies usually have the authority to determine the location of the secretariats. In some cases, the secretariat functions have been designated in the MEAs themselves (Churchill and Ulfstein 2000). For example, Article 12 of CITES determines that the Executive Director of UNEP shall provide a Secretariat. Even in this case, the location is not specified and a decision of the COP would presumably suffice to give effective guidance to UNEP's Executive Director in this respect (Oberthür 2002).

\section{Recommendation 3}

The co-location of smaller secretariats in the biodiversity cluster should be further encouraged. When deciding to establish secretariats for new MEAs that concern the conservation and/or sustainable use of the different components of biodiversity, co-location with existing secretariats in the biodiversity cluster should be pursued. In order to further enhance co-operation between MEA secretariats and increase coherence in the biodiversity cluster UNEPadministration of the Ramsar Secretariat should be considered.

\subsubsection{Co-operation among the Secretariats}

Given all the constraints, the Secretariats have actively sought solutions to enable them to work more closely together, instead of actually relocating. Therefore, co-operation at the level of the Secretariats of the MEAs in the biodiversity cluster is already well developed. Ongoing activities can be grouped in bilateral (MoUs and JWPs) and multilateral approaches (joint liaison groups).

MoUs between the MEAs is the most common form of co-operation. The MoUs are generally signed at the secretariat level and are nonbinding in nature. Memoranda of Understanding have been concluded between the following MEAs in the biodiversity cluster:

- CBD and CITES (4 January 2001)

- $\quad$ CBD and CMS (13 June 1996)

- CBD and Ramsar (10 May 2005) ${ }^{22}$

- CMS and Ramsar (18 February 1997)

- CMS and CITES (18 September 2002)

\footnotetext{
${ }^{22} 2^{\text {nd }}$ Memorandum of Co-operation.
} 
- CMS and WHC (in 2001)

- Ramsar and WHC (14 May 1999)

- $\quad$ CBD and WHC (in development)

The MoUs are commonly operationalized through joint work plans (JWP) that are adopted by mutual decisions by the respective supreme decisionmaking bodies. Joint work plans have been adopted between the following MEAs in the biodiversity cluster:

- $\quad$ CBD and Ramsar (2007-2010) $)^{23}$

- $\quad$ CBD and CITES (2000-2002)

- CBD and CMS (2002-2005)

- CMS, AEWA and Ramsar (2003-2005)

- CITES and CMS (in development)

The ability to develop the MoUs and JWPs often comes from the Secretariats. To date, this form of co-operation is developed the furthest between Ramsar and CBD (SCBD 2005). The Ramsar Convention has been recognized by the CBD COP as a lead implementation partner for wetlands. The third CBD-Ramsar Work Plan (2002-2006) includes joint action under each of the ecosystem themes of the COP and under crosscutting issues. Currently, the conventions collaborate under the fourth JWP (2007-2010).

The CBD has recognized CMS as the lead partner for migratory species. A very detailed JWP between CBD and CMS was adopted in 2002; however, only a few activities were undertaken and completed, since the Secretariats did not have the capacity to implement them in detail (EMG 2008).

Joint liaison groups represent another form of co-operation. The liaison groups are informal forums for the exchange of information and are composed of executive secretaries of the respective secretariats and other members of the convention secretariats (Chambers 2008). In 2001, a Joint Liaison Group (JLG) was established between the three Rio conventions (CBD, UNFCCC and UNCCD). In 2004, the CBD established a Biodiversity Liaison Group (BLG) between five MEAs that have biodiversity or some of its particular components as their primary concern ${ }^{24}$. The group of conventions that form the BLG are generally known as the "biodiversity-related conventions" and include CBD, CITES, CMS, Ramsar and WHC. ITPGRFA joined the BLG at its fifth meeting in September 2006. The BLG has met six times, but the practical outcomes of the BLG meetings have remained limited (EMG 2008).

Even though co-operation at the secretariat level is well developed, none of the mechanisms can be considered to coordinate the mandate,

\footnotetext{
${ }^{23} 4$ th Joint Work Plan.

${ }^{24} \mathrm{UNEP} / \mathrm{CBD} / \mathrm{COP} / 7 / 26$.
} 
functioning and priorities of the biodiversity-related MEAs in an efficient and comprehensive manner.

Bilateral approaches (JWPs and MoUs) can increase synergies only in a restricted manner, since they do not allow for finding solutions that would simultaneously apply to a variety of conventions. In addition, they might be motivated by the wrong reasons, for example, JWPs with the CBD are often motivated by getting access to GEF money (Rosendal \& Andresen 2004).

It is becoming more obvious that we need to look at the conventions at the cluster level. However, the secretariat-level clusters - the liaison groups - lack legal authority to create clear programmes that will achieve genuine co-operation between the MEAs. As a result, the liaison groups lack focus and clear mandates, so their decision-making is marginalized (Chambers 2008). The fact that the conventions are not co-located and that they are administered by different organizations is seen as a possible contributor, but also as an excuse to limit exercises to enhance synergies (EMG 2008).

Since the secretariats lack legal authority to create synergies between the MEAs and can provide only soft solutions it is essential to involve the parties in the synergy work. The AHJWG process in the chemicals and waste cluster has provided an example of a functional mechanism for involving parties in identifying concrete proposals for synergies. Consequently, it has received attention as a way forward in the IEG process and it has been proposed to offer a solution for increasing co-operation and co-ordination among other MEAs than the chemicals (EMG 2008). For example, the CBD Secretariat's statement to the Expert Panel on International Environmental Governance has described the work of the AHJWG as "a major welcomed development" and proposed that Parties of the biodiversity-related MEAs may consider launching a similar initiative (SCBD 2007a).

It should be noted that the AHJWG process cannot be directly applied to the biodiversity cluster since, in regard to scope and number of MEAs, it is much larger than the chemicals and waste cluster. However, it is possible to involve the parties in the synergy work in a manner that takes into consideration the size of the cluster and existing cooperative arrangements.

The BLG forms an existing framework that could be transformed into a mechanism that brings together the parties of the MEAs in the biodiversity cluster to consider options for synergies. The parties could meet three times in order to create joint recommendations for the adoption of the supreme decision-making bodies. Since the BLG has been created by the CBD (COP7/decision 26) as a liaison mechanism between the secretariats, changes in its mandate require a CBD decision. After this, each of the other MEAs in the biodiversity cluster would need to adopt a decision for involving parties in the BLG. 
It is important to closely examine what the strengthening of the BLG would mean in practical terms, for example, the number of parties per convention and region who would take part in its work. It would be possible to consider establishing working groups to assess thoroughly and systematically different areas for co-operation.

\section{Recommendation 4}

The Contracting Parties of the MEAs in the biodiversity cluster should assume a greater role in creating synergies between the MEAs. The BLG could be upgraded to a co-operation and co-ordination mechanism consisting of the Contracting Parties of the biodiversity-related MEAs. The Secretariats should continue to participate in the work of the BLG pursuant to their mandate. The number of meetings of the strengthened BLG could be limited to three. UNEP should be included in the BLG.

Box 4 provides valuable lessons learned from the AHJWG process in the chemicals and waste cluster.

\section{BOX 4}

\section{Why did the AHJWG work?}

Trust- and confidence-building for one

The idea to set up the AHJWG through decisions of three separate COPs was born out of a complete breakdown of trust. Stockholm COP-2 had to respond to what was felt to be a too heavy-handed top-down order "to cooperate or else..." Contracting Parties felt strongly for "their" conventions and wanted to be a part of a process discussing future cooperative mechanisms and management involving more than one autonomous legal entity. It made sense that each of the three conventions' COPs should attempt to adopt the same decisions to set up the group and thereby also nominate their set of 15 regionally nominated experts to be part of that group. UNEP participated in the group's work through resource persons taking part in the meetings, thus enabling the group to have informed discussions.

Transparency was another key feature

Much effort was put into preparing and disseminating information in an open and transparent manner: through regional consultations, through the group's website that was accessible from all three conventions' homepages, and through the co-chairs actively "spreading the word". The AHJWG managed to maintain this high degree of transparency even though it decided during its first meeting to keep its meetings solely to itself and allow no observers to take part. The AHJWG decision was taken after having carefully weighed the pros and cons. The 
pros indicated that a closer knit group would allow for more frank, open discussions and trust-building.

Keeping it short and sweet

The AHJWG's life span from the first to the third meeting was exactly one year. During this year the group produced its background documents itself, resisted the temptation to negotiate until the last meeting and entrusted its three co-chairs to draft a text to base its negotiations on.

Keeping it together

Even if the AHJWG's period of work was limited, the process itself from start to finish will take exactly three years - from Stockholm COP-2 in May 2006 being the first COP agreeing to the setting up of the group, to Stockholm COP-4 in May 2009 being the last of the COPs agreeing to the recommendation of the AHJWG and officially launching the interim period leading up to the extraordinary COPs in 2010. Such a process will have to be based on the expectation that countries and regions take part in it in a very coordinated manner.

A bold and pioneering process

It was always recognized by the constituencies to the process that in order to make it doable and worthwhile the end result would need to contain increased political visibility and clout. The simultaneous extraordinary meetings of the COPs will provide an excellent opportunity to cement the process at a high level in a very unique manner.

\subsection{Administrative and conference services}

The host institution normally provides the secretariats with administrative services and conference services. In 2003, the UN Office of Internal Oversight Services (UN OIOS) defined administrative services to include, inter alia, budget and financial management, human resources management, ICT, contracts and procurement, safety and security, building and facilities management, oversight-audit, legal services and monitoring and evaluation (Kurukulasuriya 2008). In contrast, conference services include translation, interpretation, publishing and conference planning, and co-ordination functions.

UNEP provides administrative services to the MEAs in the biodiversity cluster through two channels: the United Nations Office in Nairobi (UNON) and the United Nations Office in Geneva (UNOG).

UNON has offered administrative services to UNEP-administered MEAs since 1996. UNOG has concluded a MoU with the UNEPadministered MEA Secretariats, specifying the level and type of services 
to be provided (Inomata 2008). The administrative services of the UNEPadministered MEAs are funded through the Programme Support Cost (PSC) - a mandatory payment of 13 per cent of the MEA's core budgetary contributions.

Among UNEP-administered MEAs, UNON and UNOG provide conference services to the CITES and CMS Secretariats. Conference services are provided on a cost-recovery basis. Whereas, the CBD Secretariat sought, and was granted by COP 5 in 2000, approval to establish a conference services section costing approximately USD 500,000 per annum. This was in recognition of the high number of meetings which are organized and planned per biennium and which can exceed 50 in number (SCBD 2006b).

The Biodiversity Liaison Group has not considered options for rationalizing administrative services and conference services for the biodiversity-related MEAs (EMG 2008). It is important to note that in the chemicals and waste cluster the AHJWG assigned UNEP to clarify options for joint administrative and conference services.

\subsection{The role of organizations}

Two organizations - UNEP and IUCN - play a key role in the co-ordination, implementation and administration of the MEAs in the biodiversity cluster. The role of the Environmental Management Group is unclear.

\subsubsection{United Nations Environment Programme}

UNEP is centrally placed in the biodiversity cluster. A number of MEAs in the biodiversity cluster (CBD, CITES, CMS, AEWA, ACAP, ACCOBAMS, ASCOBANS, EUROBATS, Gorilla Agreement) are administered by UNEP.

In 1999, UNEP established the Division for Environmental Conventions (DEC) to address the growing needs of the MEAs and to try to build synergies among them. The DEC has recently merged with the legal arm of UNEP to become the DELC (Division for Environmental Law and Conventions). Various projects have been carried out to support the implementation of biodiversity-related MEAs. However, work with conventions outside UNEP's legal umbrella has proven to be challenging (Chambers 2008).

UNEP plays an important role in compiling scientific assessments and strengthening the science-policy interface on biodiversity. Since 1995 the DELC and the UNEP Division of Early Warning and Assessment (DEWA) have jointly commissioned the Global Environmental Outlook (GEO). UNEP also provided overall co-ordination for the Millennium Ecosystem Assessment. UNEP is leading a global initiative to strengthen 
the science-policy interface on biodiversity and ecosystem services (see Section 5.1.2).

Additionally, UNEP is one of the three implementing agencies of the Global Environment Facility (GEF), alongside the World Bank and the United Nations Development Programme (UNDP). UNEP has a key role in the GEF, catalyzing the development of scientific and technical analysis and advancing environmental management in GEF-financed activities (see Section 5.5).

\subsubsection{The International Union for Conservation of Nature}

IUCN has played an important role in the creation and drafting of several MEAs in the biodiversity cluster. IUCN was involved in initiating both the CBD and CITES. CITES has its origins in an IUCN Resolution in 1963 and the CBD had its origins in an IUCN Resolution in 1981 (Johnston 1999). Further, IUCN was involved in the elaboration of the preparatory text of the CMS. In addition, both the Ramsar Convention and the WHC have formal links to IUCN in their convention texts.

IUCN also plays an important role in the implementation of the biodiversity-related conventions. The Secretariat of the Ramsar Convention is provided by IUCN and is located in their headquarters in Gland, Switzerland. It is important to note that also the Secretariat of CITES was provided by IUCN, until it was taken over by UNEP (Johnston 1999). IUCN supports collaborative actions between the Ramsar Convention and other MEAs, especially CBD (through the 3rd Joint Work Plan) and CITES (through IUCN"s work on Red List assessments) (Rosendal \& Andresen 2004). IUCN also has a consultative status in the WHC (see Section 5.2.1).

IUCN and the Secretariat of the Ramsar Convention cooperate in convening the sessions of the Global Biodiversity Forum (GBF). It is an open and independent mechanism that intends to promote analysis, dialogue and partnerships in issues related to biodiversity. Hence, the GBF contributes to the further development and implementation of biodiversityrelated conventions. The GBF's effectiveness as a mechanism to engage stakeholders and build greater understanding of biodiversity has been recognized by the $\mathrm{CBD}^{25}$.

IUCN is cooperating with UNEP on many issues and their relationship has been characterized as synergistic rather than competitive. For instance, IUCN has entered into co-operation with UNEP on monitoring and assessment. The World Conservation Monitoring Centre (WCMC) was originally set up by IUCN and was later placed under the auspices of UNEP. In summary, there is an interesting potential for further synergistic co-operation between UNEP and IUCN.

\footnotetext{
${ }^{25} \mathrm{UNEP} / \mathrm{CBD} / \mathrm{COP} / 5 / 21$.
} 


\subsubsection{Environmental Management Group}

The Environmental Management Group (EMG) was established in 1999 by the UN General Assembly for the purpose of "enhancing coordination and joint action in key areas of environmental and human settlements concerns" 26 . The mandate of the group is, inter alia, to "promote inter-linkages, encourage timely and relevant exchange of data and information on specific issues and compatibility of different approaches to finding solutions to those common problems, contribute to the synergy and complementarity among and between activities of its members in the fields of environment and human settlements". ${ }^{27}$

The EMG secretariat is hosted by UNEP and the UNEP Executive Director is the chair of the Group. The secretariat is located in Geneva. The members include specialised agencies, funds and programmes of the UN system and the secretariats of MEAs. The Group has met regularly since 2001. The EMG has also established issue-management groups for harmonization of reporting on biodiversity-related conventions, sustainable procurement, and environmental aspects of water and sanitation and capacity building in the areas of biodiversity and chemicals.

To date, the Group has not been able to fulfil its co-ordination functions and there has been little high-level political engagement in its work. There has been lack of a clear sense of outcomes and limited human and financial resources. In addition, there is a negative perception of the EMG as a support body for UNEP (Kanie 2007).

Ideally the EMG could function as an effective co-ordination body between the MEAs and other UN environmental-related institutions. A draft resolution "Strengthening of environmental activities in the United Nations", was discussed in the General Assembly in late 2008. The need to strengthen the coordinative role of EMG and place it under the direct authority and leadership of the Secretary General was emphasized ${ }^{28}$. However, states were not able to agree on a resolution and the future role of the EMG remains open.

\subsubsection{A United Nations Environment Organization?}

In the context of reforming the structure of the UN in general and the IEG system in particular, there are proposals for creating a United Nations Environment Organization (UNEO). Following the 58th session of the General Assembly, the European Union made a proposal to upgrade UNEP to a UNEO. The new environment organization would build on the current UNEP, continue to be located in Nairobi and have more stable

\footnotetext{
${ }^{26}$ Resolution A/53/242 para. 5.

${ }^{27}$ UNEP/GCSS.VIII/8.

${ }^{28}$ Revised draft resolution on Agenda Item 116 "Follow-up to the outcome of the Millennium Summit” (July 23, 2008). Available at <http://www.un.org/ga/president/62/issues/environmentalgovernance.shtml>.
} 
funding. The European Union and other proponents have argued that a UNEO would be an essential tool for achieving sufficient political will to effectively address global environmental challenges (Meyer-Ohlendorf \& Knigge 2007). However, the establishment of a UNEO has come under strong political opposition.

It is important to note that in order to be able to address the creation of a new structure, it might be wise to begin from the modest end of the spectrum and gradually strengthen the new organization as trust and confidence increase (Speth \& Haas 2006). Clustering provides a "bottom-up" approach that is an essential component for increasing the confidence of the parties and, in the long run, it might prepare the way for the creation of a UNEO.

\section{Recommendation 5}

In order to be able to discuss the creation of a UN specialized agency it is essential to first clarify the composition of the different clusters and then work step by step to enhance synergies between the MEAs in the clusters and to gradually increase the confidence of the Contracting Parties. 



\section{Areas for enhanced co- operation and co-ordination in the biodiversity cluster}

This section examines five different areas for enhancing co-operation and co-ordination in the biodiversity cluster: science-policy interfaces, national reporting, information management and public awareness issues, financing, and capacity building. These areas covered here represent only a small fraction of the ones where synergies can be enhanced. Recommendations are given at the end of each presentation of an area to provide a basis for further discussions.

\subsection{Science policy interfaces on biodiversity}

Science-policy interfaces are understood as "social processes which encompass relations between scientists and other actors in the policy process, and which allow for exchanges, co-evolution, and joint construction of knowledge with the aim of enriching decision-making" (van den Hove 2007). The MEAs in the biodiversity cluster rely on a variety of science-policy interfaces (van den Hove \& Chabason 2009). Most of the MEAs have a dedicated science-policy interface in the form of scientific and technical advisory bodies, as discussed in Subsection 5.1.1. In addition, there exist several assessment mechanisms that deal with biodiversity issues (see Subsection 5.1.2). It is important to note that the inherently fragmented system of science-policy interfaces do not provide the required integrated policy support and regular assessment processes (van den Hove \& Chabason 2009).

\subsubsection{Scientific and technical bodies of the conventions}

The majority of the MEAs in the biodiversity cluster have their own subsidiary scientific body (Table 6). The mandates of the subsidiary scientific bodies have been spelled out in articles and decisions to the respective conventions. Most importantly, scientific bodies provide scientific advice to the supreme decision-making bodies on a range of aspects: technical, scientific, policy, legal and financial matters (Johnston 1999). The work of the scientific bodies is often translated into recommendations and draft decisions. 
Table 6. The scientific bodies of the MEAs in the biodiversity cluster and other MEAs and related processes linked to biodiversity (SCBD 2007b).

\begin{tabular}{|c|c|c|c|}
\hline MEA & Scientific body & Meets & Composition \\
\hline CBD & $\begin{array}{l}\text { SBSTTA } \\
\text { Article } 25 \text { of the CBD establishes an open- } \\
\text { ended intergovernmental scientific advisory } \\
\text { body known as the Subsidiary Body on } \\
\text { Scientific, Technical and Technological } \\
\text { Advice (SBSTTA) to provide the Confer- } \\
\text { ence of the Parties (COP) and, as appro- } \\
\text { priate, its other subsidiary bodies, with } \\
\text { timely advice relating to the implementation } \\
\text { of the Convention. }\end{array}$ & $\begin{array}{l}\text { Two one-week } \\
\text { meetings of the } \\
\text { SBSTTA are } \\
\text { held prior to the } \\
\text { meetings of the } \\
\text { COP. }\end{array}$ & $\begin{array}{l}\text { Government represen- } \\
\text { tatives. The SBSTTA } \\
\text { Bureau is composed of } \\
\text { ten members, led by a } \\
\text { chairperson elected by } \\
\text { the COP. }\end{array}$ \\
\hline CITES & $\begin{array}{l}\text { Animals Committee and Plants Committee } \\
\text { CITES has three scientific committees: the } \\
\text { Animals Committee, the Plants Committee, } \\
\text { and the Nomenclature Committee. The } \\
\text { Plants and the Animals Committee have } \\
\text { clear and similar mandates designed to } \\
\text { deliver specific outputs. }\end{array}$ & $\begin{array}{l}\text { The CITES' } \\
\text { Scientific } \\
\text { Committees } \\
\text { meets annually } \\
\text { for a period of } 5 \\
\text { days each. }\end{array}$ & $\begin{array}{l}\text { Each committee is } \\
\text { composed of ten mem- } \\
\text { bers, except the No- } \\
\text { menclature Committee } \\
\text { that is made up of two } \\
\text { members. }\end{array}$ \\
\hline CMS & $\begin{array}{l}\text { SC } \\
\text { Article } 8 \text { of the CMS establishes a Scientific } \\
\text { Council (SC) to provide advice on scientific } \\
\text { matters. The Council makes recommenda- } \\
\text { tions to the COP on such issues as research } \\
\text { on migratory species, specific conservation } \\
\text { and management measures, the inclusion of } \\
\text { migratory species in the Appendices and } \\
\text { designation of species for Concerted or } \\
\text { Cooperative Actions under the Convention. }\end{array}$ & $\begin{array}{l}\text { The CMS COP } \\
\text { is held every } \\
\text { three years. } \\
\text { There were two } \\
\text { meetings of the } \\
\text { SC in between } \\
\text { the two last } \\
\text { COPs that } \\
\text { lasted } 3 \text { days } \\
\text { each. }\end{array}$ & $\begin{array}{l}\text { The SC has about } 80 \\
\text { members appointed by } \\
\text { the COP or by parties. A } \\
\text { chairperson and vice- } \\
\text { chairperson are elected } \\
\text { every three years. }\end{array}$ \\
\hline Ramsar & $\begin{array}{l}\text { STRP } \\
\text { The Scientific and Technical Review Panel } \\
\text { (STRP) of the Ramsar Convention was } \\
\text { established by Resolution } 5.5 \text { (Kushiro 1993) } \\
\text { as a subsidiary body of the Convention to } \\
\text { provide scientific and technical guidance to } \\
\text { the Conference of the Parties, the Standing } \\
\text { Committee, and the Ramsar Secretariat. }\end{array}$ & $\begin{array}{l}\text { The STRP } \\
\text { usually meets } \\
\text { annually, for 4- } \\
5 \text { days. }\end{array}$ & $\begin{array}{l}\text { The STRP is composed } \\
\text { of } 13 \text { members (includ- } \\
\text { ing one chair and vice- } \\
\text { chair) appointed by the } \\
\text { STRP Oversight Com- } \\
\text { mittee. }\end{array}$ \\
\hline WHC & $\begin{array}{l}\text { Scientific advice provided by three organi- } \\
\text { sations: IUCN, ICOMOS and ICCROM. }\end{array}$ & & \\
\hline UNCCD & $\begin{array}{l}\text { CST } \\
\text { The Committee of Science and Technology } \\
\text { (CST) was established under Article } 24 \text { of } \\
\text { the Convention as a subsidiary body of the } \\
\text { COP. The committee identifies priorities for } \\
\text { research, and recommends ways of } \\
\text { strengthening co-operation among research- } \\
\text { ers. }\end{array}$ & $\begin{array}{l}\text { The CST meets } \\
\text { every two years } \\
\text { in conjunction } \\
\text { with the ordi- } \\
\text { nary sessions of } \\
\text { the COP. } \\
\text { Meetings last } 3 \\
\text { days. }\end{array}$ & $\begin{array}{l}\text { The CST Bureau is } \\
\text { composed of one } \\
\text { chairperson and four } \\
\text { vice-chairpersons. }\end{array}$ \\
\hline ICRW & $\begin{array}{l}\text { Scientific Committee } \\
\text { Article } 5.2(\mathrm{~b}) \text { requires that amendments to } \\
\text { the Schedule "shall be based on scientific } \\
\text { findings". To this end, the Commission has } \\
\text { established a Scientific Committee. }\end{array}$ & $\begin{array}{l}\text { The Committee } \\
\text { meets in the two } \\
\text { weeks immedi- } \\
\text { ately before the } \\
\text { IWC meeting. }\end{array}$ & $\begin{array}{l}\text { Is attended by approxi- } \\
\text { mately } 160 \text { scientists, } \\
\text { mainly nominated by } \\
\text { parties. }\end{array}$ \\
\hline
\end{tabular}

Depending on the convention, the meetings of the scientific bodies usually last from three to ten days. The meetings are usually held 1) prior to (CBD, ICRW); 2) in conjunction with (CCD); or 3) between (CMS, CITES) the meetings of the supreme decision-making bodies. The size and the composition of the scientific bodies vary greatly. The Subsidiary 
Body on Scientific, Technical and Technological Advice (SBSTTA) of the CBD is the largest scientific body and the average number of participants at the meetings is about 500 . The scientific bodies are funded either through the core budget of the convention (CBD, UNCCD, Ramsar) or through trust funds (CMS, CITES).

Some of the MEAs in the biodiversity conservation cluster employ environmental non-governmental organizations (ENGOs) as policy advisors. The WHC does not have a subsidiary scientific body and draws its scientific advice from three ENGOs: IUCN, ICOMOS and the International Centre for the Study of the Preservation and Restoration of Cultural Property (ICCROM). For instance, the IUCN provides monitoring for an estimated 50 sites per year and proposes new sites for the WHC. Although CITES and Ramsar have scientific bodies, they also use the expertise of ENGOs (Rosendal \& Andresen 2004). Ramsar has an independent expert group, the Scientific and Technical Review Panel (STRP), but is also aided by the IUCN, Birdlife International, Wetlands International, and the WWF. CITES has three committees, but they are aided by TRAFFIC/WWF, IUCN and UNEP-WCMC.

Options for enhanced co-operation have been considered among the scientific bodies, but to date little action has taken place. The chairs of the SBSTTA held a brainstorming meeting on ways to improve the effectiveness of the subsidiary body in Paris (24-25 July 2006). An information note on the processes and operations of the scientific bodies of the biodiversity-related convention was prepared for the consideration of the meeting (SCBD 2007b). More importantly, the chairs of scientific advisory bodies of biodiversity-related conventions have met three times to consider options for enhanced co-operation among the respective scientific and technical bodies of the conventions.

Recently, concerns have been raised that the scientific bodies of the MEAs are increasingly being politicized, thus effectively limiting scientific discussion and progress. The CBD SBSTTA has become the centre of heated debates concerning its function as the science-policy interface of the convention (Koetz et al. 2008; Laikre et al. 2008; Cressey 2008). It has developed into what many refer to as a "Mini-COP" - a body with strong political features negotiating draft decisions in preparation for the subsequent meetings of the COP (Koetz 2008). Only 7 per cent of delegates are directly from academic and research institutions.

\subsubsection{Global assessments for biodiversity}

Scientific assessments are an indispensable part of any decision-making within the MEAs and a crucial precondition for taking effective decisions (Oberthür 2002). However, the scientific bodies of the MEAs in the biodiversity cluster do not conduct scientific assessments themselves. By awarding the 2007 Peace Prize to the Intergovernmental Panel on Climate 
Change (IPCC), the Nobel Committee underscored that meaningful engagement between global science and international politics requires an effective interface (Bauer \& Stringer 2008). Apart from the IPCC, there are no fully developed science-assessment mechanisms at the international level (von Moltke 2005).

Several global assessments on biodiversity have been published since 1995 (Table 7). The Global Biodiversity Assessment (GBA) is the first comprehensive global assessment on biodiversity. It was designed, prepared and peer-reviewed by experts, but had almost no impact on policy formulation because it was conducted as a non-governmental exercise with inadequate government ownership (Watson \& Gitay 2007).

Table 7. Global assessments related to biodiversity.

\begin{tabular}{|c|c|c|}
\hline Scientific Assessment & Conducted by & $\begin{array}{l}\text { Budget and } \\
\text { primary funder }\end{array}$ \\
\hline $\begin{array}{l}\text { MA (2001-2005) } \\
\text { The Millennium Ecosystem Assessment (MA) was called for by } \\
\text { UN Secretary-General Kofi Annan in 2000. The MA is a multidis- } \\
\text { ciplinary study that assessed the consequences of ecosystem } \\
\text { change on human well-being. It was carried out during 2001- } \\
2005 \text { and involved } 1360 \text { experts worldwide (MA 2005b). The } \\
\text { findings are contained in } 5 \text { technical volumes and } 6 \text { synthesis } \\
\text { reports. UNEP provided overall co-ordination for the MA. }\end{array}$ & $\begin{array}{l}\text { UNEP } \\
\text { UNEP-WCMC } \\
\text { ICSU } \\
\text { SCOPE } \\
\text { WRI } \\
\text { etc. }\end{array}$ & $\begin{array}{l}\text { USD } 25000000 \\
\text { GEF } \\
\text { UNF } \\
\text { Packard } \\
\text { Foundation } \\
\text { World Bank } \\
\text { UNEP }\end{array}$ \\
\hline $\begin{array}{l}\text { GBA (1993-1995) } \\
\text { The Global Biodiversity Assessment project originated in July } \\
1992 \text { when the GEF Technical and Scientific Advisory Panel } \\
\text { (STAP) recommended to UNEP that a global assessment of } \\
\text { current knowledge in the field of biodiversity be carried out } \\
\text { (Heywood 1995). At the time it was the most comprehensive } \\
\text { analysis of the science of biological diversity. Over } 1100 \\
\text { scientists and experts contributed to the assessment. }\end{array}$ & & $\begin{array}{l}\text { USD } 3300000 \\
\text { GEF } \\
\text { UNEP }\end{array}$ \\
\hline $\begin{array}{l}\text { GBO (1995-) } \\
\text { The second meeting of the CBD COP called (decision1/COP2) } \\
\text { for the preparation of a periodic report on biological diversity: } \\
\text { Global Biodiversity Outlook (GBO). The first report was published } \\
\text { in } 2001 \text {. The second edition (GBO-2) was published in } 2006 \text { and } \\
\text { it shows the state and trends of biodiversity and key drivers for } \\
\text { biodiversity loss (SCND 2006c). It also highlights the relationship } \\
\text { between biodiversity and human well-being. The third edition will } \\
\text { be launched in } 2010 \text {. }\end{array}$ & $\begin{array}{l}\text { SCBD } \\
\text { UNEP-WCMC }\end{array}$ & $\begin{array}{l}\text { USD } 140000 \\
\text { SCBD }\end{array}$ \\
\hline $\begin{array}{l}\text { GEO (1995-) } \\
\text { The Global Environment Outlook (GEO) process was initiated } \\
\text { at the request of the UNEP Governing Council in } 1995 \text { to } \\
\text { create scientific information on the state of the world"s envi- } \\
\text { ronment. GEO-1 was published in 1997, Geo- } 2000 \text { in } 1999 \\
\text { and GEO-3 in } 2002 \text {. GEO- } 4 \text { was published in } 2007 \text { (UNEP } \\
2007 \text { ). It provides an overview of the social, economic and } \\
\text { environmental trends over the past two decades. More than } \\
400 \text { scientists and policy-makers, and more than } 50 \text { Collaborat- } \\
\text { ing Centres around the world participated in the assessment. }\end{array}$ & UNEP & $\begin{array}{l}\text { USD } 5500000 \\
\text { UNEP }\end{array}$ \\
\hline $\begin{array}{l}\text { FRA (1947-) } \\
\text { The Global Forest Resources Assessment (FRA) is the most } \\
\text { comprehensive assessment of the current state and recent } \\
\text { trends of forests and other wooded land. The assessment is } \\
\text { based on data that countries provide to FAO in response to a } \\
\text { common questionnaire. FAO then compiles and analyses the } \\
\text { information and presents the current state of the world"s } \\
\text { forest resources and their changes over time (FRA 2006). }\end{array}$ & FAO & FAO \\
\hline
\end{tabular}


The most comprehensive assessment on biodiversity to date is the Millennium Ecosystem Assessment (MA) that was launched in 2005. It was designed to respond to the scientific needs of the CBD, the UNCCD, the CMS and Ramsar. Two independent evaluations, one initiated by UNEP (Wells et al. 2006) and the other carried out by the United Kingdom Environmental Audit Committee of the House of Commons (House of Commons... 2007), concluded that the MA has had little impact on policy formulation and decision-making. It must be noted that the MA was only a single experiment and not a permanent science-assessment mechanism. Similarly, the first IPCC report had virtually no effect on policy-making.

Following the Conference on "Biodiversity: Science and Governance" (UNESCO, Paris, 24 to 28 January 2005), an international consultation was launched to assess the need for, scope and possible forms of an International Mechanism on Scientific Expertise on Biodiversity (IMoSEB). After two and a half years of consultation the final International Steering Committee (ISC) meeting was held in Montpellier, France, from 15 to 17 November 2007. The goal was to set up a worldwide network of expertise, similar to the IPCC. However, states were able to agree only on the "further and urgent consideration" of ways to improve the use of science in decision-making. UNEP was given the mandate to take forward the initiative in establishing an intergovernmental science-policy mechanism for biodiversity.

During CBD COP9 in Bonn, in May 2008, UNEP presented a concept note on an Intergovernmental Science-Policy Platform on Biodiversity and Ecosystem Services (IPBES) (UNEP 2008b). States welcomed the initiative that included a proposal for convening an intergovernmental meeting to consider establishing an efficient intergovernmental sciencepolicy interface on biodiversity and ecosystem services.

An ad hoc intergovernmental and multi-stakeholder meeting on an intergovernmental science-policy platform for biodiversity and ecosystem services was organized under the auspices of UNEP in Putrajaya, Malaysia, on 10-12 November 2008. The chair's report of the meeting states that participants agreed that there is a need to strengthen the sciencepolicy interface on biodiversity and ecosystem services (UNEP 2008c). However, there was uncertainty about the need for establishing a new and independent body. The meeting called for a gap analysis to support discussion on improving the science-policy interface on biodiversity and ecosystem services (UNEP 2008d). At the $25^{\text {th }}$ session of the UNEP Governing Council, the executive director was requested to convene a second intergovernmental and multi-stakeholder meeting in 2009.

There is widespread agreement that the governance of biodiversity is not as effective as it could be (van den Hove 2009; EPBRS 2009; Koetz et al. 2008). This derives in a large degree from the fact that there is no permanent external independent body of experts for issues covered by the MEAs in the biodiversity cluster, like the IPCC in the case of the 
UNFCCC (Box 5). It is becoming more obvious that the current fragmented landscape of science-policy interfaces is unable to provide the required policy support for coherent and effective decision-making (van den Hove 2009).

\section{BOX 5}

\section{Intergovernmental Panel on Climate Change}

The IPCC was established in 1988 by the World Meteorological Organization (WMO) and UNEP. The IPCC has, over the years, been firmly established as an assessment mechanism serving the Subsidiary Body on Scientific and Technological Advice (SBSTA) and the COP of the United Nations Framework Convention on Climate Change (UNFCCC). Because of its intergovernmental nature, the IPCC is able to provide scientific information in a policy-relevant, but policyneutral, way to decision-makers. To date, the IPCC has compiled four assessment reports on climate change, as well as many special reports, methodology reports and technical papers. Hence, the IPCC has had a major role in strengthening the climate regime by providing the UNFCCC with scientific and technical information relevant to understanding the impacts of climate change and options for adaptation and mitigation.

An IPBES could serve as an assessment mechanism by synthesizing global and sub-global assessments, as well as assessments on specific issues. An IPBES could also have many other functions, such as providing timely answers to specific questions emerging from policy processes and providing capacity support for data management and carrying out assessments (van den Hove 2009).

A model for an IPBES that would serve the scientific needs of several scientific bodies of MEAs in the biodiversity cluster is provided in Figure 5. The main clients would be decision-makers. At the same time, an IPBES could also serve a variety of other clients and users, such as development agencies and banks, NGOs, the private sector and the scientific community (EPBRS 2009; van den Hove 2009). 


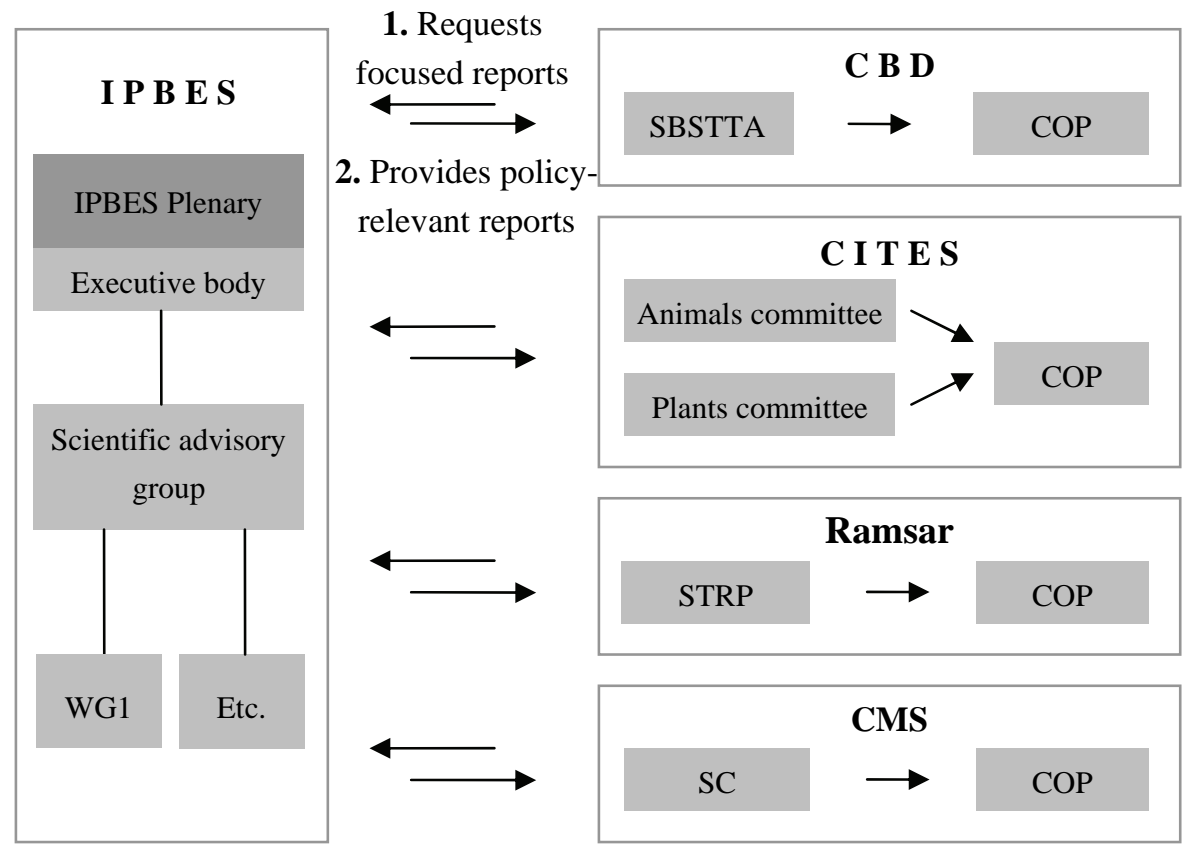

Figure 5. A main activity of an IPBES would be to publish reports on topics relevant to the implementation of the MEAs in the biodiversity cluster at the request of the scientific bodies of the conventions. In order to do so, the COPs must first clarify the relation of the scientific and technical bodies to IPBES. Then the scientific bodies can provide lists of areas in which IPBES could provide relevant inputs. At the request of the scientific bodies, IPBES would provide authoritative, scientifically credible, policy-relevant reports serving the scientific bodies and COPs of the MEAs in the biodiversity cluster.

It is important to note that the establishment of an IPBES would not lead to duplication of efforts. On the contrary, it could simply help existing structures and networks to better perform their missions and, thereby, increase effectiveness, consistency and quality of the complex international landscape of science-policy interfaces on biodiversity (van den Hove \& Chabason 2009; EPBRS 2009).

\section{Recommendation 6}

There is a need for an independent panel or platform that would provide different clients and knowledge users, in particular the scientific bodies of the MEAs in the biodiversity cluster, with timely, credible and legitimate advice. This will enable more coherent and effective decision-making to be achieved at the global, regional and national level. UNEP's initiative to establish an intergovernmental science-policy platform on biodiversity and ecosystem services (IPBES) should be supported. 


\subsection{National reporting}

Each MEA in the biodiversity cluster requires some form of reporting to its supreme decision-making body through its secretariat. Reporting to the MEAs in the biodiversity cluster is usually covered by an article of the conventions (Table 8). In the Ramsar Convention, national reporting has been introduced through a decision of the COP.

\subsubsection{Harmonization of reporting}

Harmonization of reporting is needed to increase the quality of the information and reduce the reporting burden. There is a growing recognition that the increasing reporting burden of the MEAs has led to a significant overlap and duplication of work between different reports of the biodiversity-related MEAs. There are also strong concerns that the full value of the information gathered is not being realised due to limited access and lack of comparability. The growing reporting burdens have created problems in particular for developing countries with limited institutional capacities (Oberthür 2002).

There exist several problems for harmonization of reporting. At the international level, the different reporting cycles and the different reporting formats of the MEAs pose major difficulties for harmonization. Achieving harmonisation is also challenging because of the evolving guidance on reporting occurring within each convention. At the national level, the lack of capacity and resources has been recognized as a problem. In addition, the national responsibilities for the MEAs in the biodiversity cluster are often split between different departments or agencies, making a coordinated approach to national reporting difficult. For example, responsibility for the WHC is often located in a ministry different to the environmental ministry, which is most often in charge of the other biodiversityrelated conventions (Herkenrath 2005).

The AHJWG process in the chemicals and waste cluster has introduced several proposals for the harmonization of reporting (Box 6).

\section{BOX 6}

Harmonization of reporting between the Basel and POPs MEAs

The issue of harmonizing the reporting of the Basel and POPs conventions was addressed by the AHJWG of the chemicals and waste cluster. With the view of alleviating the burden of reporting, the AHJWG proposed synchronizing the reporting cycles and streamlining the respective reporting formats and processes. In addition, in order to assist Parties in fulfilling their reporting obligations the development of joint capacitybuilding activities for coordinated data and information collection is recommended. 
Table 8. Reporting requirements of the MEAs in the biodiversity cluster and other MEAs and related processes linked to biodiversity.

\begin{tabular}{|c|c|c|}
\hline Description & Frequency & Reference \\
\hline \multicolumn{3}{|l|}{ CBD } \\
\hline $\begin{array}{l}\text { Measures parties have taken to implement the } \\
\text { provisions of the convention. Timing and content } \\
\text { of reports decided by the COP. }\end{array}$ & 4 years & Art. 26 \\
\hline \multicolumn{3}{|l|}{ CITES } \\
\hline $\begin{array}{l}\text { Annual report containing a summary of permits } \\
\text { and trade in species included in Appendices I, II } \\
\text { and III of the convention. }\end{array}$ & $\begin{array}{l}\text { Annual; by 31st October of } \\
\text { the following year. }\end{array}$ & $\begin{array}{l}\text { Art. VIII } 7 \text { b) } \\
\text { Conf. } 11.17 \\
\text { (Rev. CoP14) }\end{array}$ \\
\hline $\begin{array}{l}\text { Biennial report on legislative, regulatory and } \\
\text { administrative measures taken to enforce the } \\
\text { provisions of the convention. }\end{array}$ & $\begin{array}{l}\text { Biennial, by 31st October of } \\
\text { the following year. }\end{array}$ & \\
\hline \multicolumn{3}{|l|}{ CMS } \\
\hline $\begin{array}{l}\text { Parties to inform the secretariat of measures they } \\
\text { are taking to conserve migratory species listed in } \\
\text { Appendices I and II. }\end{array}$ & $\begin{array}{l}\text { Each COP (every two to } \\
\text { three years) }\end{array}$ & Art. VII 5 d) \\
\hline AEWA & Each ordinary meeting. & Art. V 1 c) \\
\hline ACAP & Each ordinary meeting. & Art. VII 1 c) \\
\hline ACCOBAMS & Each ordinary meeting & Art. VIII c) \\
\hline ASCOBANS & Annual; by 31st March & Art. 2.5 \\
\hline EUROBATS & Each ordinary meeting. & Art. VI \\
\hline \multicolumn{3}{|l|}{ Ramsar } \\
\hline $\begin{array}{l}\text { Submission of timely and detailed national reports } \\
\text { for the purpose of monitoring implementation of } \\
\text { the convention and for the purpose of sharing } \\
\text { information on wetland conservation measures } \\
\text { taken. }\end{array}$ & $\begin{array}{l}\text { National reports every three } \\
\text { years, six months prior to } \\
\text { each COP meeting }\end{array}$ & $\begin{array}{l}\text { Art. } 3.2 \\
\text { COP2/ Rec. } \\
2.1\end{array}$ \\
\hline \multicolumn{3}{|l|}{ WHC } \\
\hline $\begin{array}{l}\text { Parties shall in the reports they submit to the } \\
\text { General Conference of UNESCO, on dates and in } \\
\text { a manner to be determined by it, give information } \\
\text { on the legislative and administrative provisions } \\
\text { which they have adopted and other actions which } \\
\text { they have taken for the application of this Conven- } \\
\text { tion. }\end{array}$ & $\begin{array}{l}\text { 6-year periodic reporting } \\
\text { cycle }\end{array}$ & $\begin{array}{l}\text { Art. 11-12 } \\
\text { and } \\
\text { Operational } \\
\text { Guidelines }\end{array}$ \\
\hline \multicolumn{3}{|l|}{ UNCCD } \\
\hline $\begin{array}{l}\text { Each Party shall communicate reports through the } \\
\text { convention's secretariat, on measures undertaken } \\
\text { to implement the convention }\end{array}$ & $\begin{array}{l}\text { Developed country Parties } \\
\text { each CRIC (every two } \\
\text { years), Affected country } \\
\text { Parties every other CRIC } \\
\text { (every four years) }\end{array}$ & Art. 26 \\
\hline \multicolumn{3}{|l|}{ UNFF } \\
\hline $\begin{array}{l}\text { National reporting to UNFF focuses on countries' } \\
\text { progress in implementing the IPF/IFF proposals } \\
\text { for action. National reporting is voluntary. }\end{array}$ & Each year & UNFF-1 \\
\hline
\end{tabular}

The MEAs in the biodiversity cluster have provided a mandate for carrying out work on harmonization of reporting or the promotion of efficiency in the reporting requirements under relevant MEAs ${ }^{29}$. The work on harmonization of reporting has concentrated on the CBD, CITES, the CMS, Ramsar, the WHC, the AEWA and the UNCCD.

${ }^{29}$ CBD (Decisions V/23, VII/2, VIII/14 and VIII/20), CITES (Decisions 13.90 and 13.92), CMS (Resolutions 8.11 and 8.24), Ramsar (Resolutions VIII/26 and IX/5) and AEWA (Resolution 3.5). 
Numerous harmonization processes have been conducted and many are under way; however, they have all been fairly uncoordinated and have resulted in the duplication of work and different approaches to harmonization. Organizations that have contributed to the work include UNEP, UNEP-WCMC, EMG, United Nations University (UNU), CPF and the secretariats of the MEAs. The UNEP Knowledge Management (KM) project, initiated in 2006, is the main on-going project on harmonization of reporting. Recently, the Government of Australia has also worked to create a consolidated reporting template. The work on harmonization of reporting can be grouped under four different approaches (Box 7).

\section{BOX 7}

Different approaches to harmonizing reporting between biodiversityrelated MEAs

The "core report" concept

The "core report" concept is based on the Human Rights Treaty System, where parties submit a core report to all treaties and shorter specific reports to individual treaties. The Australian Government's Department of the Environment, Water, Heritage and the Arts (DEWHA) has been developing a single consolidated reporting template for $\mathrm{Pa}$ cific Island countries (PICs) for five biodiversity-related MEAs (CBD, CITES, CMS, Ramsar and WHC) (Australian Government 2008). There are seventeen sections in the core reporting template and five "supplementary information" sections (one for each of the biodiversity-related conventions). The reporting template is designed to be completed on a triennial cycle. In July 2008 the consolidated template was tested by four PICs (Cook Islands, Fiji, Kiribati and Samoa). The PICs were supportive of the consolidated reporting template and the implementation of the consolidated reporting process. The consolidated reporting template is currently out for comment with the MEA Secretariats.

The "modular approach"

When the requirements of the various biodiversity-related conventions and agreements are analysed, the activities and information required can be organized into series of clusters or modules. The idea of the "modular approach" is that the organization of information manage ment in a modular manner leads to more efficient information management and use, which supports both implementation and reporting. In 2005, the CMS COP called for the harmonization of reporting with other biodiversity-related MEAs through the development of common reporting modules (Resolution 8.24). The UNEP Knowledge Management (KM) project is exploring the feasibility of developing com- 
mon reporting modules for the CMS, AEWA and IOSEA. The common reporting modules can be seen as a step forward in the development of a comprehensive joint national reporting system for all biodiversity-related conventions and agreements. The work is done in parallel with the development of an online reporting facility (see below).

Joint thematic reporting formats

It has been argued that it will be difficult to develop one single report that serves the needs of all the MEAs, since the MEAs have differences in scope, periodicity and nature of required information. In contrast, developing a joint report format for shared thematic issues is considered a practical solution for harmonizing reporting. The UNEP KM project has produced two desk-studies about the feasibility of creating joint thematic reporting formats. The studies present two thematic reporting frameworks, which build on the overlaps in the reporting elements for the UNCCD and CBD programmes of work on dry and sub-humid lands (Tyrrell 2007), and for the Ramsar and CBD programmes of work on inland waters (Tyrrell 2008).

Joint reporting portals

In July 2002, the Collaborative Partnership on Forests (CPF) established a CPF Task Force on Streamlining Forest-Related Reporting. The CPF Task force identified the main bodies that reported on forestrelated issues. These are the CBD (national reports and thematic reports), the CSD (national reports), FAO (FRA and forest products), the ITTO (world timber situation and progress towards SFM in tropical forests), the UNCCD (national reports), the UNFCCC (national communications and greenhouse gas inventories), and the UNFF (national reports on implementation of IPF/IFF proposals for action). A joint reporting portal was created to provide details online of what information the bodies collect. The task force considered the possibility of organizing the information in the reports according to the seven elements of Sustainable Forest Management (SFM) adopted at UNFF-4. It was soon noticed, however, that extracting information from the existing reports was time consuming and therefore the process was not pursued further at this stage.

\subsubsection{Online reporting}

Online reporting is a new tool that has the potential to facilitate reporting further. Online reporting allows Focal Points to continuously update their national reports, by adding new information as it becomes available, and by inviting contributions from relevant stakeholders.

Online reporting is now rapidly evolving through the CMS family. In 2006, the first online reporting system was introduced for the Marine 
Turtles IOSEA ${ }^{30}$. Based on the positive experiences from IOSEA, a CMS-funded initiative - System of Online National Reporting (SONAR 2010) - intends to create a comprehensive online reporting system for the CMS family by 2010. In 2008, an online reporting tool was introduced for the AEWA. Recently, similar tools have been established for the CMS and CITES biennial reports. By 2010, the project intends to further introduce online reporting for nine MoUs and several regional agreements (ASCOBANS, EUROBATS and ACCOBAMS). UNEP-WCMC has been contracted as the project manager on behalf of the CMS family. In addition, the Ramsar Convention has developed an electronic reporting format in recent years, but reporting is not online yet.

\section{Recommendation 7}

There is a lack of capacity in secretariats to adequately address harmonization of reporting. If progress is to be made with the harmonization of reporting, then governments need to be involved. A strengthened BLG, consisting of government representatives, should look at harmonization of reporting by building on existing initiatives. A consolidated reporting template and a uniform reporting cycle should be introduced to the MEAs in the biodiversity cluster. In addition, online reporting of MEAs in the biodiversity cluster could gradually be expanded to include the entire biodiversity cluster.

\subsection{Information management and public awareness issues}

Information management and public awareness issues are important for strengthening the implementation of the biodiversity-related MEAs.

\subsubsection{Information management}

Creating information management tools is essential for facilitating data accessibility and improving guidance for national implementation. Two web-based knowledge management tools are under development. In addition, a joint website has been developed.

UNEP and IUCN are jointly developing a web-based tool - Tematea Issue-based modules for coherent implementation of biodiversity-related conventions - that provides information on common issues by identifying and grouping articles, decisions, resolutions and recommendations of several global and regional biodiversity-related MEAs ${ }^{31}$. Tematea offers a thematic approach to the national implementation of biodiversity-

\footnotetext{
${ }^{30}$ IOSEA Marine Turtle - Online Reporting Facility: http://www.ioseaturtles.org/report/.

${ }^{31}$ Website of Tematea Issue-based modules for coherent implementation of biodiversity-related conventions: http://www.tematea.org.
} 
related (MEAs). Tematea can be utilized, for example, when preparing for international negotiations (COPs), as the webpage can help identify gaps and synergies between the MEAs that should be further targeted. So far, modules for the following thematic issues have been developed: inland waters, invasive alien species, sustainable use, biodiversity and climate change, and protected areas.

UNEP is also developing another web-based tool - the MEA Knowledge Management Portal ${ }^{32}$. It allows access to key documents (articles, decisions, resolutions and strategic plans) of five biodiversity-related agreements (CBD, AEWA, CITES, CMS and Ramsar) and to the IOSEA MoU. The MEA knowledge management tool differs from Tematea by providing the accurate documents related to the search word. In contrast, Tematea provides a simplified result of the articles or decisions.

A joint website has been created between the CBD, CITES, the CMS, the WHC, Ramsar and the ITPGRFA ${ }^{33}$. The current joint website is part of the CBD website and it does not represent a website that would be a true entry point to the MEAs in the biodiversity cluster.

\section{Recommendation 8}

The development of information management tools for the MEAs in the biodiversity cluster should continue to progress. The joint website should be further developed into an entry point to a 'biodiversity cluster portal". It could be structured to include the information management tools (Tematea and Informea) as well as the online reporting systems.

\subsubsection{Public awareness issues}

Public education and awareness are essential to establishing an enabling environment for the public to participate in conservation initiatives. The MEAs in the biodiversity cluster contain specific provisions that recognize the importance of public awareness to the implementation of the conventions. For example, the CBD (Art. 13) requires Parties to promote the understanding of biodiversity and the measures required at the national level, whereas, the WHC (Art. 27) requests Parties to create educational and information programmes to strengthen appreciation and respect of the cultural and natural heritage. In this context, it is important to note that in 2002 the CBD COP adopted a decision on a programme of work for the global initiative on communication, education and public awareness (CEPA) ${ }^{34}$.

There exist some examples of common approaches to public awareness issues. Most importantly, the BLG has developed an interactive CD-

\footnotetext{
${ }^{32}$ Website of the MEA Knowledge Management Portal: http://www.informea.org/.

${ }^{33} \mathrm{http} / / / \mathrm{www} . \mathrm{cbd}$.int/blg/.

${ }^{34} \mathrm{UNEP} / \mathrm{CBD} / \mathrm{COP} / 6 / 19$.
} 
ROM on the application of the Addis Ababa Principles and Guidelines (AAPG) for the Sustainable Use of Biodiversity within the biodiversityrelated conventions.

\section{Recommendation 9}

A common approach to awareness and outreach activities among the MEAs in the biodiversity cluster should be developed. This would increase the visibility of biodiversity-related issues and enhance public awareness. Full use should be made of existing information and outreach activities and these should be further enhanced.

\subsection{Financing}

Adequate financing is without question one of the key factors for effective implementation of MEAs (Chambers 2008). For example, it has been estimated that in the early 1990s the budgets for protected areas amounted to only about 20 per cent of what was actually needed to maintain a comprehensive protected area system (SCBD 2004). The lack of financial resources is often cited as the primary reason why especially developing countries do not implement and comply with global environmental MEAs (Chasek et al. 2006). Between 1998 and 2003, official development assistance (ODA) earmarked for biodiversity decreased by an average of 6 per cent per year (SCBD 2006c).

The Global Environment Facility (GEF) is the largest multipurpose facility to provide funding for the implementation of MEAs. It serves as the financial mechanism for the CBD, the UNFCCC, the UNCCD and POPs, and provides grants for projects related to six focal areas: biodiversity, climate change, international waters, land degradation, the ozone layer, and persistent organic pollutants. As illustrated in Table 9, the financial potential, in comparison with the funds allocated by the GEF for the CBD, of the other MEAs indicates that they have no chance of becoming really effective as long as the present situation continues. 
Table 9. Fund or financial mechanism for the MEAs in the biodiversity cluster and other MEAs and related processes linked to biodiversity.

\begin{tabular}{|c|c|}
\hline MEA & Fund or financial mechanism \\
\hline CBD & $\begin{array}{l}\text { GEF } \\
\text { Biodiversity projects constitute the largest percentage of GEF"s portfolio, making } \\
\text { up } 36 \% \text { of total GEF grants. Between } 1991 \text { and } 2006 \text {, the GEF provided approxi- } \\
\text { mately USD } 2.2 \text { billion in grants, and leveraged about USD } 5.2 \text { billion in co- } \\
\text { financing in support of more than } 750 \text { biodiversity projects in } 155 \text { countries. }\end{array}$ \\
\hline CMS & $\begin{array}{l}\text { CMS Small Grants Programme } \\
\text { Since } 1997 \text { the Programme has supported over } 50 \text { projects, distributing nearly } \\
\text { USD1.5 million in capacity building and training projects. } \\
\text { AEWA Small Conservation Grant Fund } \\
\text { The AEWA SGF was established by the Meeting of the Parties at its first Session in } \\
\text { 1999. }\end{array}$ \\
\hline Ramsar & $\begin{array}{l}\text { Ramsar Small Grants Fund } \\
\text { Established by Ramsar COP4 in } 1990 \text { as a mechanism to assist developing coun- } \\
\text { tries and those with economies in transition in implementing the Convention and to } \\
\text { enable the conservation and wise use of wetland resources. The fund has provided } \\
\text { funding and co-funding to approximately } 198 \text { projects in about } 87 \text { countries, total- } \\
\text { ling about } 7.5 \text { million Swiss francs. } \\
\text { Wetlands for the Future Fund } \\
\text { Since 1997, the Ramsar Secretariat, the US State Department, and the US Fish } \\
\text { and Wildlife Service have operated the Wetlands for the Future Fund (WFF) to } \\
\text { promote the capacity of Latin American and Caribbean countries in managing their } \\
\text { wetlands. }\end{array}$ \\
\hline WHC & $\begin{array}{l}\text { World Heritage Fund } \\
\text { The World Heritage Fund provides about USD } 4 \text { million annually to support Parties } \\
\text { in need of assistance in identifying, preserving and promoting World Heritage sites. } \\
\text { It includes compulsory and voluntary contributions from the Parties, and from } \\
\text { private donations. The World Heritage Committee allocates funds according to the } \\
\text { urgency of requests, with priority being given to the most threatened properties. }\end{array}$ \\
\hline UNCCD & $\begin{array}{l}\text { GEF } \\
\text { In } 2003 \text {, the GEF was designated a financial mechanism of the UNCCD. Over the } \\
\text { next three years, the GEF expects to invest more than USD } 250 \text { million in projects } \\
\text { that promote sustainable land management. }\end{array}$ \\
\hline
\end{tabular}

Apart from the CBD, the MEAs in the biodiversity cluster do not have a financial mechanism, for example, CITES has never benefited from the GEF, even indirectly through the CBD window (Inomata 2008). The annual costs of staffing and maintaining a national CITES office and implementing activities on the ground level remain unaffordable for many developing countries.

In contrast, Ramsar has succeeded at connecting with MEAs that have better access to financing, and it has put into operation projects that have improved its level of overall financing. A good example of this is the River Basin Initiative that is designed to implement the CBD's Programme on Inland Waters and Biological Diversity (Chambers 2008).

Enhancing synergies in financing can lead to cost-effectiveness, which can make financing go further. This has been clearly demonstrated by the inclusion of land degradation and persistent organic pollutants as focal areas for the GEF, as well as the designation of the GEF as the financial mechanism for the UNCCD. Before the designation of land degradation as one of the focal areas of the GEF, projects that aimed at the preserva- 
tion of soil had to come under one of the other areas, for instance, biodiversity or international water management, to be eligible for funding. Such a proceeding lacked focus and from an environmental perspective the designation of the GEF as the financial mechanism of the UNCCD must be considered progress (Matz 2005).

As opposed to the creation of a variety of smaller trust funds, the MEAs employing the GEF as their financial mechanism profit from the size of the institution in regard to financial and human resources and knowledge.

\section{Recommendation 10}

The GEF should be developed and strengthened by including further focal areas and further treaty-specific services for the MEAs in the biodiversity cluster. Inadequate funding hampers the effective implementation of the MEAs in many developing countries. This includes the inability or difficulty of most MEAs in the biodiversity cluster to access support from the GEF. In particular, the lack of funding affects the development of synergies and cooperative activities between the conventions.

It should also be noted that the development of a funding mechanism similar to that of the Montreal Protocol would allow more funding for the MEAs in the biodiversity cluster. Between 1990 and 2008 the multilateral fund for the implementation of the Montreal Protocol has received contributions from some 49 OECD countries totalling over USD 2.4 billion. This has enabled over 6000 projects and activities in 148 countries to be carried out with the aim of phasing out ozone-depleting substances. The multilateral fund has been explained as a major factor for the success of the Montreal Protocol.

Recently, the importance of engaging the business community in the conservation and sustainable use of biodiversity has been underlined as a way to increase funding and enhance the implementation of biodiversityrelated MEAs. Globally, several meetings have been organized and several initiatives have been developed to mobilize the business community on biodiversity.

Some businesses have already realized that biodiversity consideration gives them positive consumer response. Besides complying with local and national legislation, businesses are increasingly adopting voluntary measures to promote the conservation and sustainable use of biodiversity. The measures include, inter alia, giving donations to conservation projects, concluding operational partnerships with ENGOs and integrating biodiversity considerations into corporate strategies and policies. 


\section{Recommendation 11}

In order to enhance the engagement of the business community and increase the overall funding of biodiversity measures, national and regional Business and Biodiversity initiatives should be adopted. In the long term, this will allow companies to fully integrate biodiversity into all business models and to develop new business opportunities linked to biodiversity conservation.

\subsection{Capacity building}

Capacity building is essential to facilitate implementation of the biodiversity-releated MEAs. All the MEAs in the biodiversity cluster require parties to strengthen human resources and institutional capacities in developing countries and countries with economies in transition. Parties should promote coordinated implementation of the decisions of the supreme decision-making bodies in the area of capacity building. For example, enhancing co-operation among the different Focal Points of the MEAs in the biodiversity cluster would facilitate the exchange of information and enable the creation of networks that would greatly enhance the implementation of the MEAs.

\section{Recommendation 12}

Parties should develop joint capacity building activities that apply to all of the conventions in the biodiversity cluster. 



\section{Final remarks}

It is common that through treaty-learning, best practices and lessons learned are incorporated into the design and decision-making of other MEAs. Until recently, the MEAs in the biodiversity cluster have lacked a strong model to guide co-operation and co-ordination efforts. This report has shown, most importantly, that the contracting parties must be involved in the design, implementation and follow-up of synergistic solutions. The AHJWG process in the chemicals and waste cluster has provided a model for involving the Parties in the synergies work. In addition, the IPCC, which functions as a science-assessment mechanism for the UNFCCC, has provided a model for improving the science-policy interface on biodiversity. These models clearly show the way forward, although they should not be directly applied to the biodiversity cluster, but specific modifications should be adjusted as necessary.

The MEAs in the biodiversity cluster have seen the number of ratifications grow steadily. During the past years there has even been quite a step growth in the number of new parties and, in fact, it has even been argued that we have moved into a new "implementation" era (UNEP 2009). So far, only the CBD has reached almost universal membership. However, it can be expected that it is only a matter of time before the other MEAs in the biodiversity cluster reach similar levels of ratifications. From the Nordic countries, Denmark, Finland, Norway and Sweden are already Parties of all six MEAs (including the Cartagena Protocol) in the biodiversity cluster. Thus, it is now time to look forward, and new approaches for enhancing synergies should not be rejected by the perception that the MEAs all still have slightly different compositions of State Parties.

It may well be that synergistic benefits are only achievable if one adopts an issue-specific approach. This means that no one biodiversity cluster of MEAs can be formed to cover effectively all issues. On the contrary, specific issues (e.g. secretariats, reporting, scientific assessments, services) should be dealt with in specified sub-clusters of MEAs that represent the most potential combination for enhancing co-operation and co-ordination. For example, in the case of the supreme decisionmaking bodies the greatest potential for creating synergies presumably lies in a sub-cluster of two conventions - the CBD and the ITPGRFA.

This report has not covered the issues of enhancing synergies among the three Rio conventions (CBD, UNFCCC and UNCCD). However, it is clear that the Rio conventions form a broader realm and significant opportunities exist for enhancing synergies among these three conventions. Even a party-driven process similar to the AHJWG process might be considered for the Rio conventions. 



\section{References}

Andresen, S. 2007. The effectiveness of UN environmental institutions. Int. Env. Agreements 7: 317-336.

Australian Government 2008. Report: Outcomes of the trial of the consolidated reporting template for Pacific Island countries to the biodiversityrelated multilateral environmental agreements. October 2008. 51 pp.

Bauer, Steffen \& Stringer, Lindsay C. 2008. Science and policy in the global governance of desertification. An analysis of institutional interplay under the United Nations Convention to Combat Desertification. Global Governance Working Paper No. 35 - February 2008.

Calestous, J. 2008. The Future of the International Whaling Commission: Strengthening Ocean Diplomacy. Report, International Whaling Commission. May 16, 2008.

Chambers, W. B. 2008. Interlinkages and the Effectiveness of Multilateral Environmental Agreements. United Nations University Press, Tokyo, Japan. 311 pp. Chasek, Pamela S., Downie, David L. \& Brown, Janet Welsh. 2006. Global Environmental Politics. 4th edition-Westview Press, Boulder, Colorado. 350 pp.

Churchill, Robin R. \& Ulfstein, G. 2000. Autonomous Institutional Arrangements in Multilateral Environmental Agreements: A Little-Noticed Phenomen in International Law. The American Journal of International Law 94: 623-659.

Cressey, D. 2008. Biodiversity body “lacks science". Nature 454: 809.

EMG (Environmental Management Group) 2008. Enhancing MEAs' coherence. Analysis of existing cooperative frameworks and proposals for MEAs' co-operation and synergies, in particular lessons learned and successful examples, and identification of areas where further co-operation might be explored. EMG Secretariat. First Unedited Draft. 29 January 2008.
EPBRS (European Platform for Biodiversity Research Strategy) 2008. Concept note: Network of knowledge for biodiversity governance. The European Platform for Biodiversity Research Strategy: promoting knowledge for sustainability. 17 pp.

FAO (Food and Agriculture Organization) 2006. Global Forest Resources Assessment 2005, Main Report. Progress Towards Sustainable Forest Management. FAO Forestry Paper 147. FAO.

Gillespie, A. 2001. Small Cetaceans, International law and the International Whaling Commission. Melbourne J. Int'l L 257: 261-265.

Herkenrath, P. 2005. Options for harmonizing national reporting to biodiversity-related agreements. UNEP World Conservation Monitoring Centre.

Heywood, V.H. (ed.) 1995. The Global Biodiversity Assessment. United Nations Environment Programme. Cambridge University Press, Cambridge. $1140 \mathrm{pp}$.

Holst, L. J. 1999. Elements for a more cost-efficient global governance of the biodiversity-related conventions.

Conference paper. To the Inter-linkages - International Conference on Synergies and Co-ordination between Multilateral Environmental Agreements, Tokyo, 14-16 July 1999. 14 p.

House of Commons Environmental Audit Committee 2007. The UN Millennium Ecosystem Assessment. The Stationery Office Limited, London. 48 pp.

Inomata, T. 2008. Management review of environmental governance within the United Nations System. Joint Inspection Unit. JIU/REP/2008/3.

Johnston, S. 1999. Principles of International Environmental Law. In: Swanson, T. \& Johnston, S. (eds.). Global Environmental Problems and International Environmental Agreements. The Economics of International Institution Building, p. 203-263. Edward Elgar Publishing, Northampton, USA. 
Kanie, N. 2007. Governance with Multilateral Environmental Agreements: A Healthy or Ill-Equipped Fragmentation? In: Global Environmental Governance: Perspectives on the Current Debate. Swart. L. \& Estelle, P. (eds.). Center for UN Reform Education, New York. p. 67-86.

Knigge, M., Herweg, J. \& Huberman J. 2005. Geographical Aspects of International Environmental Governance, Illustrating Decentralisation. Ecologic, Institute for International and Environmental Policy. 11 p.

Koetz, T., Bridgewater, P., van den Hove, S. \& Siebenhüner, B. 2008. The role of the Subsidiary Body on Scientific, Technical and Technological Advice to the Convention on Biological Diversity as science-policy interface. Environmental Science \& Policy II: 505-516.

Kurukulasuriya, L. 2008. Report of the legal personality of the Ramsar Secretariat. Ramsar COP10 Doc. 35.

Laikre, L., Jonsson, B-G, Ihse, M., Marissink, M., Gustavsson, A.-M. D., Torbjörn, E., Hagberg, L., Stål, P.-O., von Walter, S. \& Wrammer P. 2008. Conservation Biology 22: 814-815.

MA 2005a. Ecosystems and Human Wellbeing: Biodiversity Synthesis. World Resources Institute, Washington, DC. $86 \mathrm{p}$.

MA 2005b. Millennium Ecosystem Assessment 2005. Ecosystems and Human Well-being: Synthesis Report. World Resources Institute, Washington, DC. $137 \mathrm{p}$.

Matz, Nele 2005. Financial Institutions between Effectiveness and Legitimacy - A Legal Analysis of the World Bank, Global Environment Facility and Prototype Carbon Fund. International Environmental Agreements 5: 265-302.

Meyer-Ohlendorf, N. \& Knigge M. 2007. A United Nations Environment Organization. Excerpts from "Global Environmental Governance - Perspectives on the Current Debate", Published in 2007 by the Center for UN Reform Education. p. 124-141.

Najam, A., Papa, M. and Taiyab, N. 2006. Global Environmental Governance: A Reform Agenda. International Institute for Sustainable Development. Winnipeg, Canada. 114 pp.
Nordic Council of Ministers 2006. For a rich future -13 conventions on the natural and cultural environment. TemaNord 2006:565. Nordic Council of Ministers, Copenhagen. 41 pp.

Oberthür, S. 2002. Clustering of Multilateral Agreements: Potentials and Limitations. International Environmental Agreements: Politics, Law and Economics 2: 317-340.

Rosendal, G. K. \& Andresen, S. 2004. UNEP's Role in Enhancing ProblemSolving in Multilateral Environmental Agreements - Co-ordination and Assistance in the Biodiversity Conservation Cluster. Paper prepared for the 45th ISA Conference, Montréal. 17-21 March 2004. 29 p.

SCDB (Secretariat of the Convention on Biological Diversity) 2004. Donor guide to the Convention on Biological Diversity. Secretariat of the Convention on Biological Diversity. Montréal, Canada. 230 pp.

SCBD 2006a. Options for enhanced cooperation among the biodiversityrelated conventions. UNEP/CBD/WGRI/1/7/add.2. 14 July 2005.

SCBD 2006b. Administration of the Convention and the Budget for the programme of work for the biennium 2007-2008. Audit of the Secretariat of the Convention on Biological Diversity: draft report. $\mathrm{UNEP} / \mathrm{CBD} / \mathrm{COP} / 8 / \mathrm{INF} / 44$.

SCBD 2006c. Global Biodiversity Outlook 2. Secretariat of the Convention on Biological Diversity. Montréal, Canada. $81 \mathrm{pp}$.

SCBD 2007a. Statement by Ahmed Djoghlaf, Executive Secretary of the Convention on Biological Diversity to the Expert Panel on International Environmental Governance. New York, 1 May 2007.

SCBD 2007b. Information on the processes and operations of scientific bodies of Rio conventions, biodiversity-related conventions and the global environment facility. UNEP/CBD/WGRI/2/INF/12/Add.2. 16 April 2007.. SCBD 2008. Co-operation with other conventions, international organizations and initiatives and engagement of stakeholders. UNEP/CBD/COP/9/21/ Add.1. 
Siebenhüner, B. 2007. Administrator of global biodiversity: The secretariat of the convention on biological diversity. Biodivers. Conserv. 16: 259-274.

Speth, James Gustave \& Haas, Peter M. 2006. Global Environmental Governance. Island Press. Washington. 179 p.

Tyrrell, T. 2007. Joint Reporting on Drylands for the Convention on Biological Diversity and the United Nations Convention to Combat Desertification. A report from the UNEP Knowledge Management project. 22 pp.

Tyrrell, T. 2008. A Joint Reporting Framework on Inland Waters for the Convention on Biological Diversity and the Ramsar Convention on Wetlands. A report from the UNEP Knowledge Management project. 66 pp.

UN (United Nations) 2007. International Consultative Process on the Institutional Framework for the United Nations' Environmental Activities. CoChairs' Options Paper. New York. 14 June 2007.

UNEP (United Nations Environment Programme) 2007. Global Environment Outlook: environment for development (GEO-4). Progress Press Ltd, Malta. $540 \mathrm{pp}$.

UNEP 2008a. Information provided by the Secretariat of the Convention on Biological Diversity on its experience in organizing back-to-back meetings (Draft). UNEP/FAO/CHW/RC/ POPS/JWG.3/INF/4. 29 February 2008. UNEP 2008b. Concept note: An Intergovernmental Science-Policy Platform on Biodiversity and Ecosystem Services - Building on the global strategy for follow-up to the Millennium Ecosystem Assessment (MA) and the consultative process towards an International Mechanism of Scientific Expertise on Biodiversity (IMoSEB) Services.

UNEP 2008c. Report of the ad hoc intergovernmental and multi-stakeholder meeting on an intergovernmental science-policy platform on biodiversity and ecosystem services. UNEP/IPBES/ 1/6 12. November 2008.
UNEP 2008d. Preliminary gap analysis for the purpose of facilitating discussions on how to strengthen the sciencepolicy interface. UNEP/GC.25/INF/30. 26 January 2006.

UNEP 2009. International Environmental Governance and United Nations Reform, “IEG: Help or Hindrance?" IEG from a country perspective. Background information paper for the ministerial-level consultations, Discussion paper presented by the Excecutive Director. UNEP/GC.25/16/Add.1

UNEP, University of Joensuu and Environment Canada 2007. Multilateral Environmental Agreements - Negotiator's handbook. Second Edition. Saarijärven offset, Saarijärvi.

van den Hove, S. 2007. A rationale for science-policy interfaces. Futures 39, p. 807-826.

van den Hove, S. \& Chabason, L. 2009. The debate on an intergovernmental science-policy platform on biodiversity and ecosystem services (IPBES): Exploring gaps and needs. Iddri - Idées pour la débat $\mathrm{N}^{\circ} 01 / 2009$. Draft version 2 February 2009.

von Moltke, K. 2001. On clustering International Environmental Agreements. Winnipeg. IISD. June 2001.

von Moltke, K. 2005. Clustering international environmental agreements as an alternative to a World Environment Organization. In: A World Environment Organization. Solution or Threat for Effective International Environmental Governance? F. Biermann and S. Bauer (Eds.). Ashgate, Aldershot, UK. p. 175-204.

Watson, R.T. \& Gitay, H. 2007. Sciencepolicy interface: The role of scientific assessments. Case study conducted in the framework of the consultative process towards an IMoSEB. 21 pp.

Wells, M. P., Grossman, D. \& Navajas, H. 2006. Terminal Evaluation of the UNEP/GEF Project "Millennium Ecosystem Assessment”. UNEP, Evaluation and Oversight Unit. 



\section{Svensk resumé}

Förhandlingar rörande reformen av den internationella miljöförvaltningen (IEG) har förts i mer än ett decennium. För närvarande verkar det osannolikt att en betydande omstrukturering av IEG kommer att ske inom den närmaste framtiden. Därför presenteras i rapporten en stegvis klusterbildning som ett sätt att stärka IEG-processen. Genom att gå in för en s.k. "bottom-up"-infallsvinkel och betrakta miljökonventionerna i tematiska kluster torde det vara möjligt att hitta lösningar för att öka samarbetet och samordningen mellan miljökonventionerna i mindre helheter. Detta gör det möjligt att bygga upp en mer koherent IEG, där nationella behov beaktas och där form följer funktion.

För närvarande finns 155 konventioner som behandlar biologisk mångfald på någon nivå. Fyra urvalskriterier har använts för att identifiera miljökonventioner som skulle bilda ett sammanhängande och väldefinierat biodiversitetskluster:

1. Konventionen gäller i första hand bevarande av biologisk mångfald och hållbart nyttjande.

2. Konventionen samarbetar med andra biodiversitetskonventioner.

3. Konventionen kan inte grupperas under andra kluster

4. Konventionen har en internationell karaktär och minst 90 fördragsslutande parter.

Utifrån dessa kriterier skulle biodiverstitetsklustret inledningsvis kunna omfatta följande sex miljökonventioner:

CBD Konventionen om biologisk mångfald

CITES Konventionen om internationell handel av utrotningshotade arter

CMS Konventionen om flyttande arter

Ramsar Ramsarkonventionen om våtmarker

WHC Världskultursarvskonventionen

ITPGRFA Internationella traktaten on växtgenetiska resurser

För närvarande har åtgärder för att stärka synergierna mellan biodiversitetsrelaterade miljökonventioner vidtagits relativt osystematiskt, utan något särskilt samordnande angreppssätt. Detta har lett till dubbelarbete och till att områden där synergier är möjliga inte har utforskats. Man kan till och med hävda att det till dags dato har presenterats väldigt få - om några alls - genuint synergistiska lösningar för biodiversitetsrelaterade miljökonventioner. 
Denna rapport innehåller tolv rekommendationer som avser att stärka samarbetet och samordningen mellan miljökonventionerna i det ett preliminärt biodiversitetskluster. Rekommendationerna är preliminära och representerar ingen uttömmande analys. De viktigaste observationerna och rekommendationerna sammanfattas nedan.

Antalet veckor som de högsta beslutsfattande organen för biodiversitetsklustrets sex miljökonventioner har tillbringat i sammanträden har ökat snabbt sedan Stockholmskonferensen år 1972. Att ordna samtidiga eller på varandra följande möten för de högsta beslutsfattande organen skulle kunna medföra fördelar (t.ex. minskade totalkostnader och minskade inkonsekvenser i beslutsfattningen). Samtidigt skulle detta också medföra praktiska nackdelar av olika slag (t.ex. alltför långa möten med alltför många deltagare eller höga kostnader) som gör detta till ett ogenomförbart alternativ. I kontrast bör förfarandet att ordna på varandra följande möten för olika organ inom miljökonventionerna fortsättningsvis uppmuntras i situationer då detta alternativ medför fördelar (Rekommendation 1). Vidare bör de alltför omfattande föredragningslistorna för de högsta beslutsfattande organens möten begränsas genom att fokusera på de mest väsentliga frågorna. Detta skulle kunna bidra till en gradvis förkortning av mötena och även hjälpa att fastställa prioriteringar för implementeringen (Rekommendation 2).

Sekretariaten för biodiversitetsklustrets miljökonventioner finns på olika håll i världen och de administreras av olika mellanstatliga organisationer (IGOn). Möjligheterna att samplacera miljökonventionernas sekretariat har diskuterats, men det verkar som om det inte finns några större utsikter för en mer omfattande omorganisering av sekretariaten inom biodiversitetsklustret. Den enda sammanslagningen av sekretariat som gjorts kommer från sekretariatet för Avtalet om skydd av småvalar i Östersjön, Nordöstra Atlanten, Irländska havet och Nordsjön (ASCOBANS), som slogs samman med dess moderkonvention (CMS) år 2006. Även om resultaten av denna samplacering fortfarande är oklara, verkar det som om samplacering av mindre sekretariat är utförbart och fortsättningsvis bör uppmuntras. Vid beslut att grunda sekretariat för nya miljökonventioner som gäller skydd och/eller hållbart nyttjande av olika komponenter inom biologisk mångfald, bör man sträva efter att förlägga de nya sekretariaten i anslutning till befintliga sekretariat inom biodiversitetsklustret. I syfte att ytterligare stärka samarbetet mellan miljökonventionernas sekretariat och öka koherensen inom biodiversitetsklustret bör man överväga att överföra Ramsar-sekretariatet till UNEP:s administration (Rekommendation 3).

Biodiversitetsklustrets miljökonventioner har ett välutvecklat samarbete på sekretariatsnivå. De sex miljökonventionerna inom biodiversitetsklustret samarbetar på sekretariatsnivå genom samarbetsmekanismen för sekretariat (Biodiversity Liaison Group - BLG) och bilaterala arrangemang (Memorandum of Understanding, MoU och gemensamma ar- 
betsprogram). BLG bildades år 2004, och detta bör betraktas som ett stort framsteg i bildandet av ett miljökonventionskluster. Sekretariaten saknar emellertid juridisk behörighet att utveckla ett genuint samarbete och en samordning mellan miljökonventionerna. Därför har BLG:s arbete endast gett begränsade praktiska resultat. Sammanfattningsvis kan man konstatera att, eftersom samarbetet har varit begränsat till sekretariatsnivå, har konventionerna inte kunnat stärka synergierna mellan miljökonventionerna effektivt eller ens samordna befintliga initiativ ordentligt.

Rapporten betonar att de fördragsslutande parterna bör ta en större roll för att skapa synergier mellan miljökonventionerna. Det arbete den gemensamma arbetsgruppen (Ad Hoc Joint Working Group on enhancing co-operation and co-ordination among the Basel, Rotterdam and Stockholm conventions - AHJWG) utfört i syfte att stärka samarbetet och samordningen mellan Basel-, Rotterdam- och Stockholmskonventionerna har visat fördelarna med en fördragspartsbaserad process, där strukturer och organisationer skapas utifrån nationella behov. Modellen kan emellertid inte tillämpas direkt på biodiversitetsklustret, eftersom klustret är så mycket störrem både vad gäller konventionernas antal och omfattning. Likväl skulle man kunna omvandla BLG till ett forum som också omfattade de fördragsslutande parterna. Det är viktigt att bedöma vad detta skulle innebära i praktiken, bland annat hur många parter per konvention och region som skulle medverka i arbetet (Rekommendation 4).

UNEP innehar en nyckelroll när det gäller biodiversitetsklustret, eftersom organisationen administrerar tre miljökonventioner (CBD, CMS och CITES) och de sju regionala avtalen i CMS-familjen. Europeiska unionen har föreslagit att UNEP omvandlas till FN:s miljöorganisation United Nations Environment Organization UNEO. Men för att det ska vara möjligt att diskutera inrättandet av en specialiserad FN-organisation är det viktigt att först klargöra de olika klustrens sammansättning och sedan arbeta stegvis för att stärka synergierna mellan miljökonventionerna $\mathrm{i}$ klustren och gradvis öka de fördragsslutande parternas förtroende (Rekommendation 5).

Miljökonventionerna i biodiversitetsklustret stöder sig på olika slag av gränssnitt för växelverkan mellan vetenskap och politik. Helheten av dessa gränssnitt är emellertid splittrad och kan inte ge det stöd som följdriktig och effektiv beslutsfattning kräver. Miljökonventionernas vetenskapliga och tekniska organ blir alltmer politiserade, och de saknar nödvändig finansiering och personal. Vidare finns det ingen fullt utvecklad vetenskaplig utvärderingsmekanism för biodiversitet på internationell nivå. Det finns ett behov av en oberoende panel eller plattform som skulle förse klienter och informationsanvändare, i synnerhet de vetenskapliga organen för biodiversitetsklustrets miljökonventioner, med rättidiga, trovärdiga och legitima råd. UNEP:s initiativ att grunda en mellanstatlig plattform för biodiversitet och ekosystemtjänster (IBPES) bör stödas (Rekommendation 6). 
Harmonisering av den nationella rapporteringen lyfts ofta fram som ett av de viktigaste områdena då det gäller att minska den administrativa arbetsbördan och genom detta underlätta den nationella implementeringen. Flera harmoniseringsprocesser har genomförts och många är på gång. De har emellertid varit relativt splittrade och gett upphov till dubbelarbete och olika infallsvinklar. Framsteg inom harmoniseringen av rapporteringen fordrar att regeringarna engageras i frågan. En starkare BLG som består av representanter för regeringarna bör se över harmoniseringen av rapporteringen utifrån de befintliga initiativen (Rekommendation 7).

Vidare kunde en förstärkt BLG medverka bland annat i den fortsatta utvecklingen av informationshanteringsredskap och en gemensam webbplats (Rekommendation 8), samt i utvecklingen av en gemensam syn på kampanjer och informationsmaterial för allmänheten bland biodiversitetsklustrets miljökonventioner (Rekommendation 9).

Utöver CBD har biodiversitetsklustrets miljökonventioner ingen ekonomisk mekanism. De övriga miljökonventionernas ekonomiska potential, i jämförelse med de medel som beviljas av Global Environment Facility (GEF) för CBD, pekar på att de inte kan bli riktigt effektiva under rådande omständigheter. GEF bör utvecklas och stärkas genom att komplettera det med fler fokusområden och fler konventionsspecifika tjänster för miljökonventionerna i biodiversitetsklustret (Rekommendation 10). Utveckling av en finansieringsmekanism i likhet med den multilaterala fonden för implementering av Montrealprotokollet skulle också möjliggöra ytterligare finansiering för miljökonventionerna i biodiversitetsklustret. För att öka den totala anslagen till biodiversitetssektorn bör arbetet för att engagera företagen uppmuntras genom nationella och regionala affärs- och biodiversitetsinitiativ (Rekommendation 11).

Aktiviteterna för tekniköverföring och kapacitetsutveckling har ofta bristande koherens. Inom det bilaterala utvecklingssamarbetet bör man utveckla ett gemensamt angreppssätt för implementeringen av biodiversitetsrelaterade miljökonventioner. Exempelvis målen för biodiversitetsklustrets miljökonventioner bör integreras med de nationella strategier och handlingsplaner för biologisk mångfald (National Biodiversity Strategies and Actions Plans, NBSAP) som verkställs inom ramen för CBD. Vidare skulle åtgärder för att stärka samarbetet mellan olika kontaktpunkter (Focal Points) för biodiversitetsklustrets miljökonventioner underlätta informationsutbytet och göra det möjligt att skapa nätverk som betydligt stärker implementeringen av miljökonventionerna (Rekommendation 12). 
Annexes 


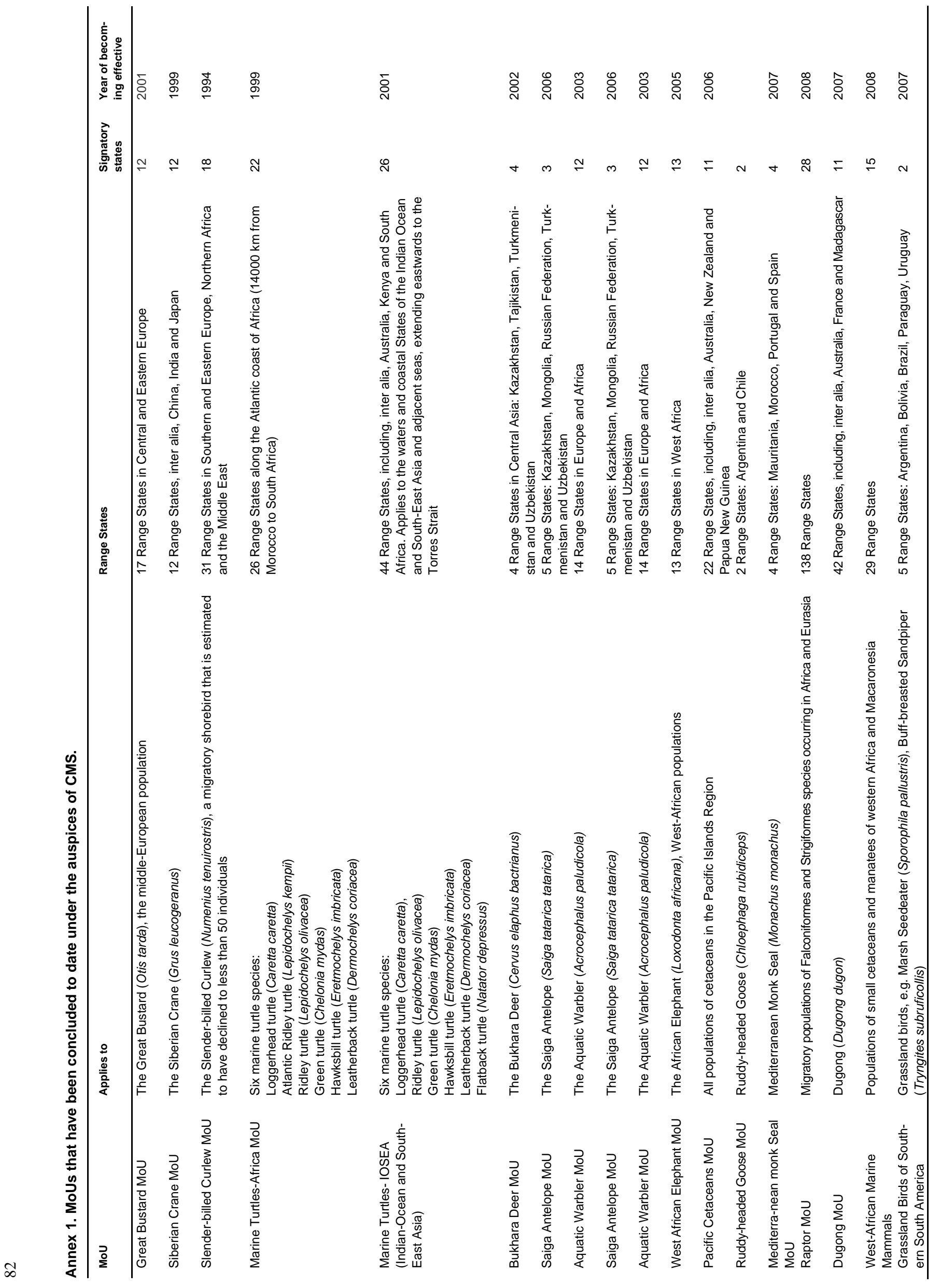


$\infty$

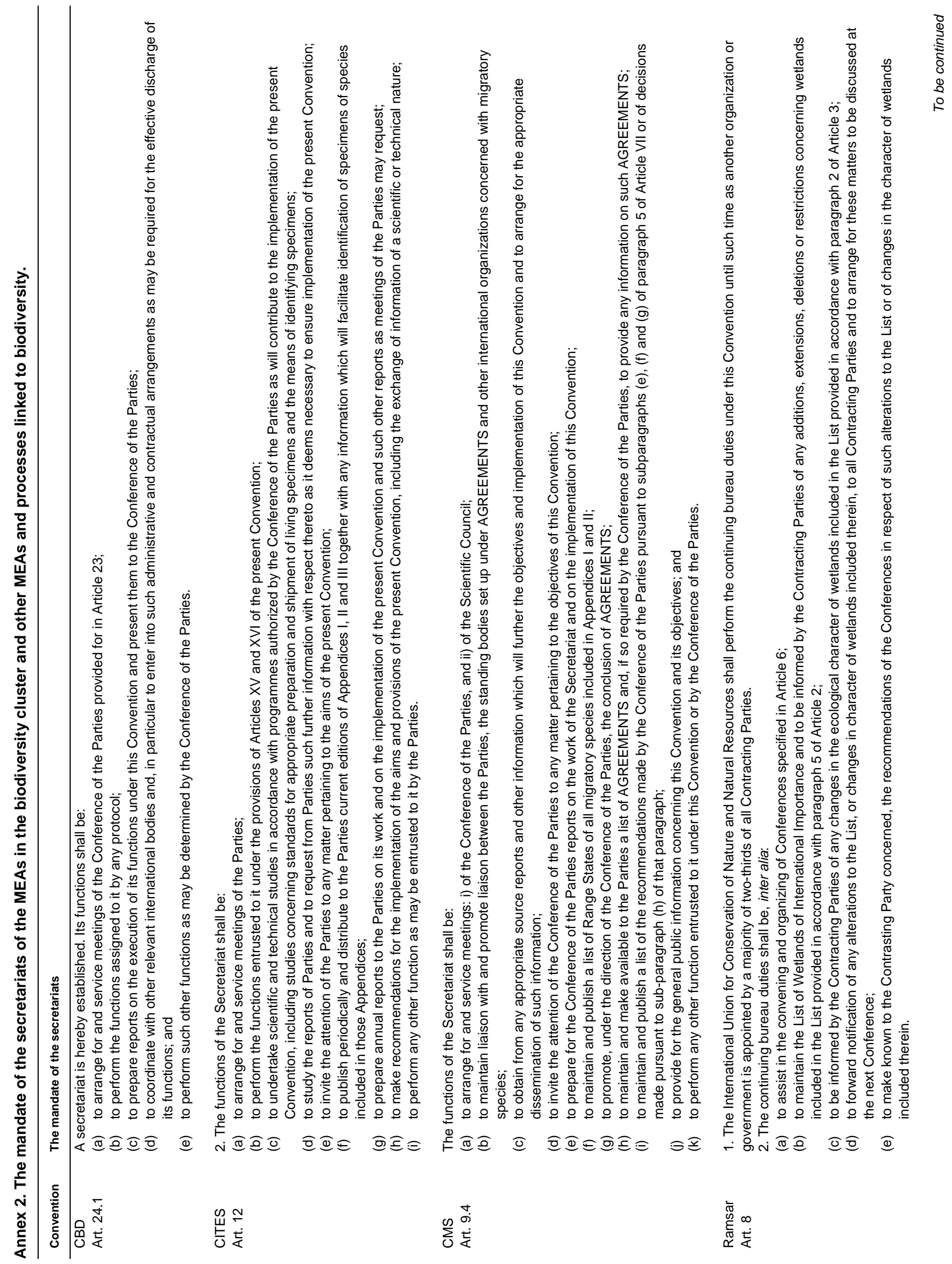




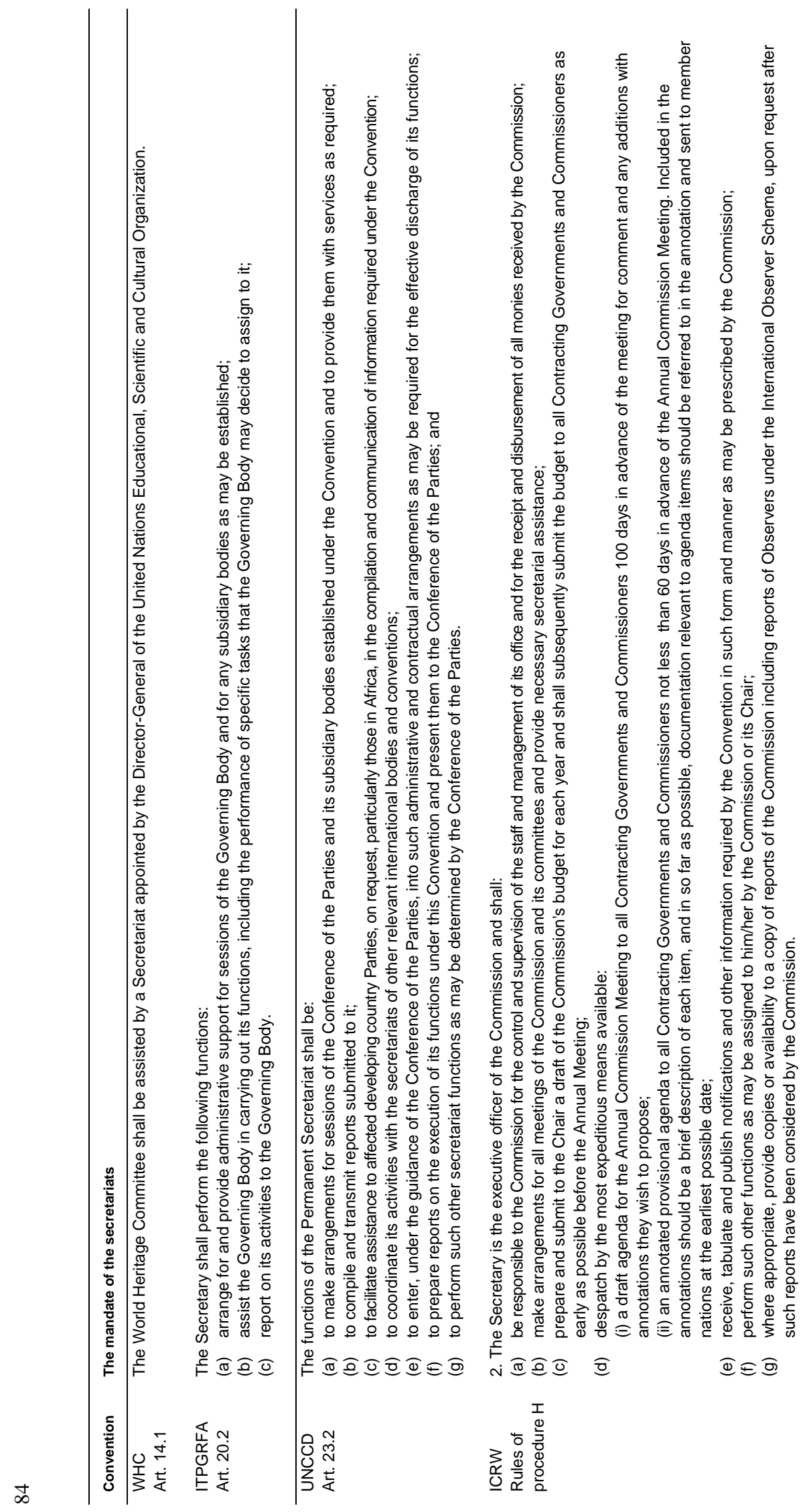


